\title{
Timing and conditions of brittle faulting on the Silltal-Brenner Fault Zone, Eastern Alps (Austria)
}

\author{
Neil Mancktelow $\cdot$ Horst Zwingmann • \\ Marion Campani • Bernhard Fügenschuh • \\ Andreas Mulch
}

Received: 29 September 2014/Accepted: 25 February 2015/Published online: 23 April 2015

(C) Swiss Geological Society 2015

\begin{abstract}
The Silltal Fault is the northern brittle continuation of the Brenner Fault Zone, marked by a narrow zone of cataclasis and, in three locations, clay-rich fault gouges. The clay mineral composition of these gouges is dominated by higher temperature $2 \mathrm{M}_{1}$ polytype illite/muscovite, with no $1 \mathrm{M} / 1 \mathrm{M}_{\mathrm{d}}$ illite or mixed layer illite/ smectite detected. Smectite is limited to the northern samples from the Stephansbrïcke location, whereas chlorite is present in all samples. The $\mathrm{K}-\mathrm{Ar}$ ages from the different sample size fractions $(<0.1,<0.4,<2,2-6$, 6-10 $\mu \mathrm{m}$, "whole rock gouge") show a wide spread, from ca. 115 to $12 \mathrm{Ma}$, with ages consistently decreasing with grain size. Although the ranges overlap, ages from the northern Stephansbrücke samples are generally older (115-36 Ma) than those from the south near Matrei
\end{abstract}

Editorial handling: E. Gnos.

Electronic supplementary material The online version of this article (doi:10.1007/s00015-015-0179-y) contains supplementary material, which is available to authorized users.

N. Mancktelow ( $\square)$

Department of Earth Sciences, ETH Zurich,

8092 Zurich, Switzerland

e-mail:mancktelow@erdw.ethz.ch

H. Zwingmann

CSIRO, Earth Science and Resource Engineering,

Kensington 6151, WA, Australia

H. Zwingmann

School of Earth and Environment, The University of Western

Australia, Crawley, WA 6009, Australia

H. Zwingmann

Department of Applied Geology, Curtin University,

Bentley, WA 6845, Australia
(55-12 Ma), possibly reflecting increasing regional metamorphic temperatures to the south. The well-defined linear relationship between apparent age and hydrogen stable isotope $(\delta \mathrm{D})$ values establishes a direct correlation between rejuvenation of the $\mathrm{K}-\mathrm{Ar}$ system and increased interaction with meteoric water introduced and focussed within the fault zone. The dependence of both apparent age and $\delta \mathrm{D}$ on grain size also indicates that radiogenic and stable isotope exchange was controlled by grain size, reflecting new $2 \mathrm{M}_{1}$ illite growth, mechanical grinding of protolith muscovite during cataclastic faulting, or both. The results demonstrate the advantages of combining radiogenic and stable isotope analysis in interpretation of $\mathrm{K}-\mathrm{Ar}$ ages from clay fault gouges. The combined approach was necessary to establish the crucial influence on apparent $\mathrm{K}-\mathrm{Ar}$ ages of meteoric water influx focussed on the fault zone and its interaction with clay-size-fraction grains.

Keywords Clay fault gouge Illite $\cdot \mathrm{K}-\mathrm{Ar}$ dating . H-isotopes · Silltal-Brenner Fault Zone · Eastern Alps

M. Campani - A. Mulch

Biodiversity and Climate Research Centre (BiK-F) and Senckenberg Research Institute, Senckenberganlage 25, 60325 Frankfurt, Germany

B. Fügenschuh

Institute of Geology, University of Innsbruck, Innrain 52, 6020 Innsbruck, Austria

A. Mulch

Institute of Geoscience, Goethe University Frankfurt, Altenhöferallee 1, 60438 Frankfurt, Germany 


\section{Introduction}

The Silltal Fault is usually taken to be the direct continuation along strike of the younger brittle part of the Brenner Fault Zone, which forms the western boundary of the Tauern Window (Fig. 1; Schmidegg 1953, 1964; Frank et al. 1987; Behrmann 1988; Selverstone 1988; Fügenschuh et al. 1997, 2000; Rosenberg and Garcia 2011). The Brenner Fault Zone is one of two major low-angle normal faults that mark the western boundaries of regional-scale tectonic windows in the Alps: the other example is the Simplon Fault Zone limiting the Lepontine Metamorphic Dome in the Central Alps. These two fault systems appear to be directly analogous, developing mainly in the period from $\sim 20$ Ma to present and reflecting important orogenparallel extension during ongoing Alpine convergence (Mancktelow 1985, 1992; Behrmann 1988; Selverstone 1988; Prey 1989; Grasemann and Mancktelow 1993; Fügenschuh et al. 1997, 2000; Campani et al. 2010a, b). The two fault zones involve regional exhumation of both hanging wall and footwall but whereas the hanging wall remained brittle, the more rapidly exhuming footwall underwent a transition from a broad zone of higher grade ductile mylonites to more localized brittle faulting during cooling. The latest relative displacement was localized on a discrete brittle fault marked by cataclasites and locally by clay fault gouge, as investigated here along the Silltal Fault.

Foliated clay fault gouges from the Stephansbrücke clay pit (e.g. Schmidegg 1953) preserve kinematic indicators indicating a normal sense typical of the Brenner Fault Zone further to the south and have been used as geological field evidence for quite recent movement on a continuous Silltal-Brenner Fault Zone (Reiter et al. 2005). However, until now there were no age data available to constrain the time of formation of this fault gouge. Clay fault gouges are typical of many important brittle faults active under relatively low metamorphic grade, near surface conditions (e.g. Engelder 1974; Rutter et al. 1986). If authigenic illite is present, such gouges can reliably date the timing of fault activity (e.g. Lyons and Snellenburg 1971; Kralik et al. 1987; Van der Pluijm et al. 2001; Zwingmann and Mancktelow 2004; Zwingmann et al. 2004, 2010a, 2011; Solum et al. 2005; Solum and van der Pluijm 2007; Surace et al. 2011; Pleuger et al. 2012; Clauer 2013; Viola et al. 2013; Yamasaki et al. 2013; Bense et al. 2014; Torgersen et al. 2014a). In this study, samples of clay fault gouge associated with the Silltal Fault were collected for $\mathrm{K}-\mathrm{Ar}$ dating from the Stephansbrücke clay pit in the north and from two exposures some $8 \mathrm{~km}$ further to the SE.

Undeformed and recrystallized phyllosilicates (white mica, biotite, chlorite) were also collected along a broad profile from the brittle hanging wall into the mylonitic

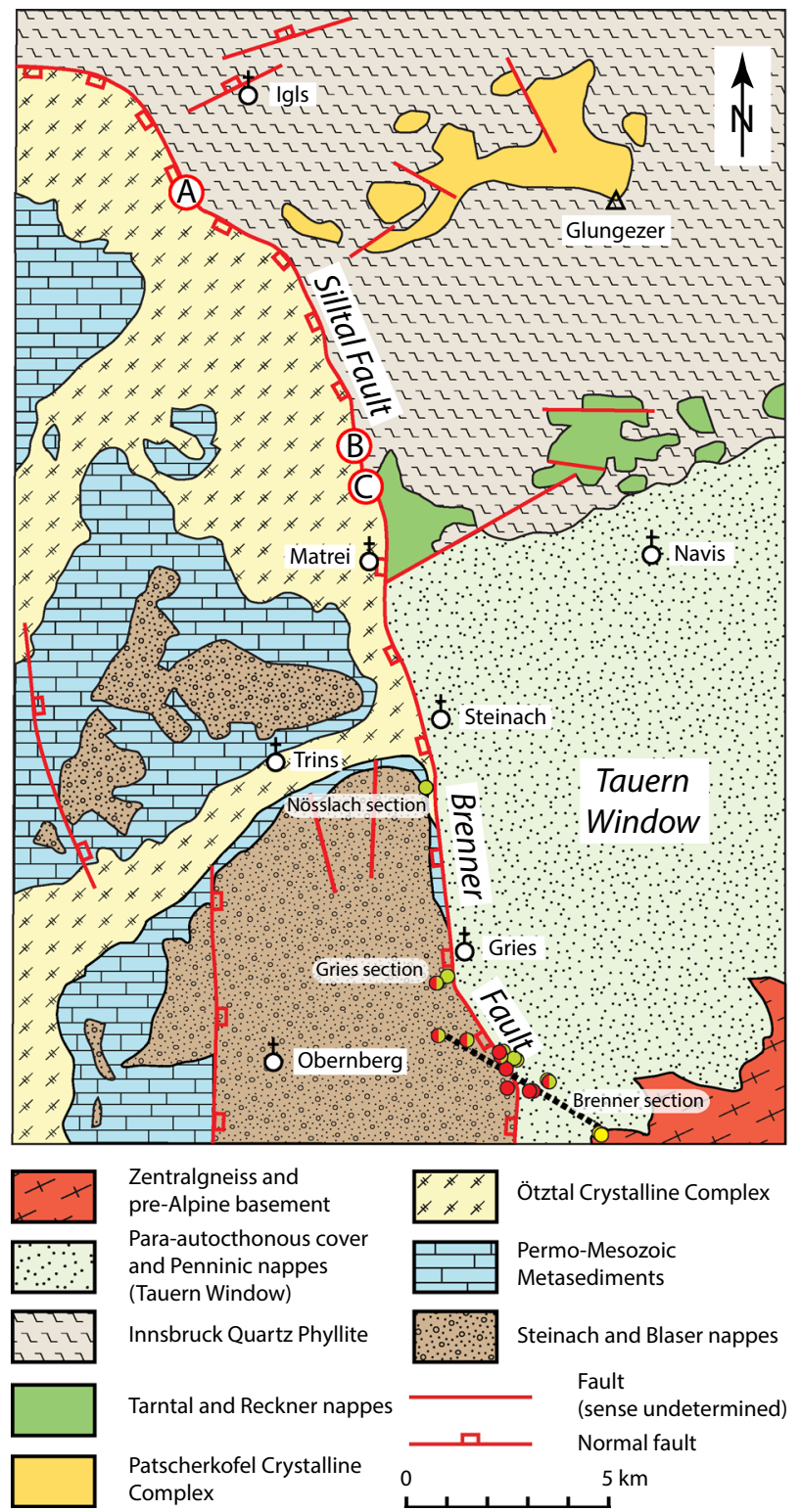

Fig. 1 Tectonic sketch map of the area north of the Brenner Pass, Austria (redrawn after Decker et al. 2009). Locations are: A Stephansbrücke (samples SB1, SB2, SB3, SB4); $B$ (sample BF1) and $C$ (sample BF2), which are the two localities further south near Matrei. Note that at sample locations $A$ and $B$, the footwall unit is the Innsbruck Quartz Phyllite, whereas for $C$ it is the Reckner nappe, which is assigned to the lower Austroalpine Matrei Zone. Small coloured circles represent phyllosilicate samples collected across the Brenner Fault Zone, near Steinach (Nösslach section), Gries (Gries section) and close to the Brenner Pass (Brenner section). Red circles correspond to muscovite, yellow to biotite and green to chlorite samples

footwall of the Brenner Fault Zone further to the south (Fig. 1), with this profile corresponding to a telescoped crustal section through the detachment system. Similar to Hetzel et al. (2013), H-isotope data were obtained from the 
dated clay fractions, as well as from phyllosilicates collected across the wider shear zone, in order to identify the fluid source(s) involved and possible syndeformational fluid pathway(s) within the crustal detachment. A particular aim was to assess the possible deep influx of surfacederived water along or close to the detachment, as had previously been established for the Simplon Fault Zone (Campani et al. 2012).

The measured (apparent) K-Ar ages for different clay size fractions generally decrease with decreasing grain size, as also reported in many studies from other areas (e.g. Hower et al. 1963; Pevear 1999), and range from Early Cretaceous to Middle Miocene. There are various possible interpretations of this grain size dependence in clay fault gouges, including physical mixtures of protolith and authigenic mica and clay (Pevear 1999; Vrolijk and van der Pluijm 1999; Van der Pluijm et al. 2001; Haines and van der Pluijm 2008), growth of different clays and polytypes during ongoing fault movement (Zwingmann et al. 2010a; Viola et al. 2013; Bense et al. 2014; Torgersen et al. 2014a), and grain-size dependent loss of Ar, due to thermally activated diffusion (Dodson 1973) or promoted by intracrystalline deformation in a hydrothermal environment (Villa 1998; Mulch et al. 2002; Mulch and Cosca 2004). The current study employs a multi-faceted approach to investigate the relationship of measured $\mathrm{K}-\mathrm{Ar}$ ages to clay mineralogy, potential protolith contamination, fluid source (e.g. metamorphic or meteoric) and degree of fluid-rock interaction. Such a broad approach is crucial for (1) critically assessing different possible interpretations of $\mathrm{K}-$ Ar dates from clay fault gouges developed in protoliths that contain metamorphic white mica, and (2) constraining the timing and conditions of brittle faulting on the SilltalBrenner Fault Zone in the Eastern Alps.

\section{Geological overview}

The fault gouge samples collected for this study come from clay-rich zones developed at, or immediately adjacent to, the contact between hanging and footwall units of the Silltal Fault. The Silltal Fault runs NNW from the NW corner of the Tauern Window in the Eastern Alps and marks the boundary between two distinctly different units, the Ötztal Crystalline Complex to the west and the Innsbruck Quartz Phyllite to the east (Fig. 1). The fault is marked by a cataclastic zone and locally by clay-bearing gouge (Fügenschuh 1995), though outcrop conditions along the fault trace are generally poor (Decker et al. 2009).

In more recent publications, the Silltal Fault is invariably considered to be the northerly continuation of the brittle component of the Brenner Fault Zone, with an effectively normal (i.e., top-down-to-W) sense of movement
(Behrmann 1988; Selverstone 1988; Prey 1989; Ratschbacher et al. 1991; Fügenschuh 1995; Fügenschuh et al. 2000; Linzer et al. 2002; Reiter et al. 2005; Glodny et al. 2008; Rosenberg and Garcia 2011). However, there is a change in the units comprising the footwall at the junction of the continuous Silltal-Brenner Fault Zone with the northern boundary of the Tauern Window (Fig. 1): south of this triple-point, the footwall dominantly consists of calcschists from the Penninic Glockner nappe (e.g. Frisch 1974) and, north of here, generally of upper Austroalpine Innsbruck Quartz Phyllite. In the area directly north of the Tauern Window, units of the lower Austroalpine Tarntal and Reckner nappes locally also occur in the immediate footwall of the Silltal Fault (Fig. 1) (Koller 2003; Töchterle et al. 2011). Further to the north, the Patscherkofel Crystalline Complex (Rockenschaub et al. 2003; Piber et al. 2008; Decker et al. 2009) occurs as a klippe on top of the Innsbruck Quartz Phyllite (Fig. 1). This klippe crops out on a slope dipping ca. $20^{\circ}-30^{\circ}$ to the west and projection down-dip suggests that it should be transected by the Silltal Fault near the Stephansbrücke clay pit locality (Location A, Fig. 1).

In general, the Innsbruck Quartz Phyllite preserves a pre-Alpine greenschist facies metamorphic mineral assemblage, whereas units from the Tauern Window record later Alpine greenschist to amphibolite facies metamorphism (e.g. Hoernes and Friedrichsen 1974). Radiometric mineral ages reflect this difference in Alpine metamorphic grade on the northern boundary of the Tauern Window: in the Innsbruck Quartz Phyllite, ${ }^{40} \mathrm{Ar} /{ }^{39} \mathrm{Ar}$ results for white mica typically give Late Permian or Triassic to Jurassic ages, whereas the corresponding ages in the Tauern Window are Oligocene to Miocene (Fig. 2). There is also a marked jump in fission track ages, for zircon from ca. 10 to $16 \mathrm{Ma}$ in the Tauern Window to ca. 35-60 Ma north of it and for apatite from ca. 9 to $13 \mathrm{Ma}$ (Fig. 2; Fügenschuh 1995; Fügenschuh et al. 1997). The ${ }^{40} \mathrm{Ar} /{ }^{39} \mathrm{Ar}$ white mica ages in the Patscherkofel Crystalline Complex klippe show a wide range but with two main peaks at around 149-180 Ma (Middle Jurassic) and 123-136 Ma (Early Cretaceous) (Rockenschaub et al. 2003). One retrograde mylonitic gneiss from the base of the Patscherkofel Crystalline Complex shows a white mica ${ }^{40} \mathrm{Ar} /{ }^{39} \mathrm{Ar}$ age spectrum with steps between 50 and $120 \mathrm{Ma}$, and two marked plateaux at 51 and $72 \mathrm{Ma}$ (Rockenschaub et al. 2003). Rockenschaub et al. (2003) note that these ages are markedly younger than those from the overlying Patscherkofel Crystalline Complex and interpret these younger ages down to $50 \mathrm{Ma}$ to reflect retrograde metamorphism and mylonitization at the base of this allochthonous klippe, possibly related to its top-to-west final emplacement. From the similarity in lithology and thermobarometric estimates, Piber et al. (2008) suggest the 


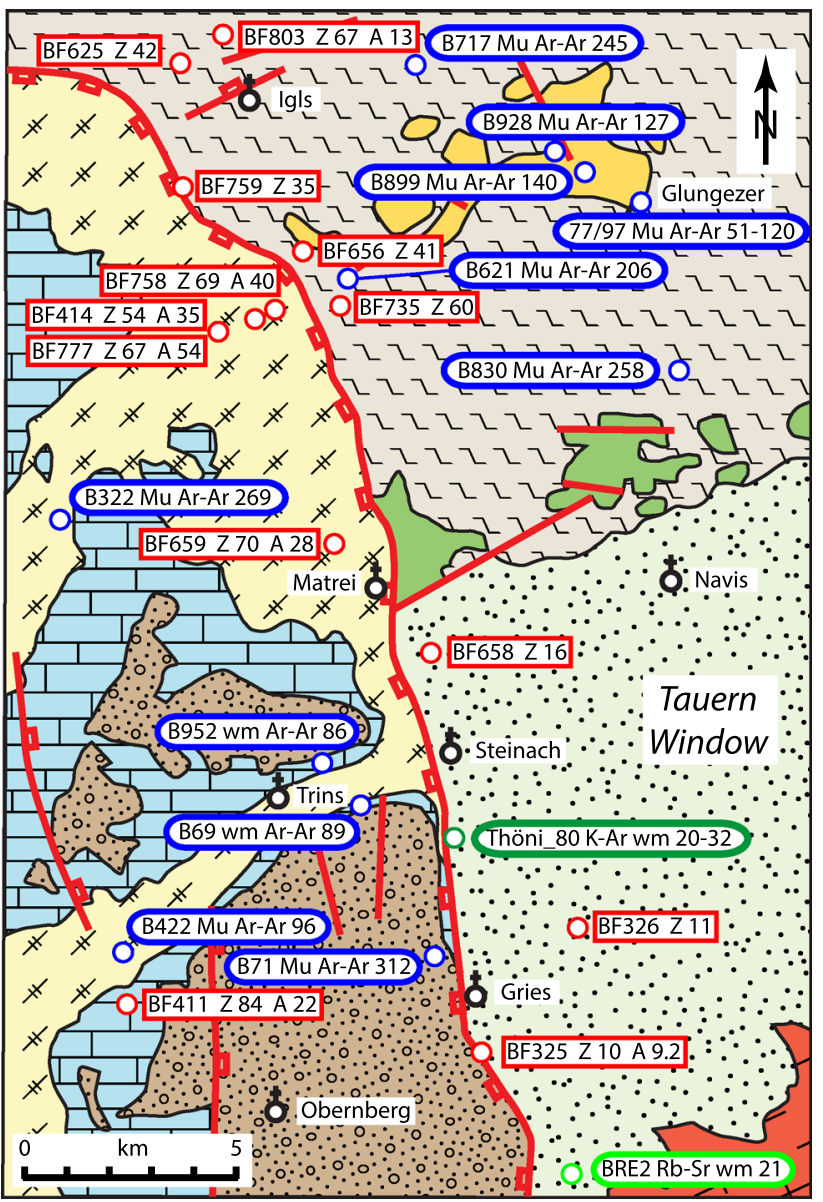

Fig. 2 Summary of published geochronological data from the area of Fig. 1. Red rectangles are zircon (Z) and apatite (A) fission track ages (Fügenschuh 1995; Fügenschuh et al. 1997, 2000), blue banners for ${ }^{40} \mathrm{Ar} /{ }^{39} \mathrm{Ar}$ white mica ages (Rockenschaub et al. 2003), dark green banner for $\mathrm{Rb}-\mathrm{Sr}$ white mica results (Thöni 1980 and light green banner for $\mathrm{Rb}-\mathrm{Sr}$ white mica results (Glodny et al. 2008)

Patscherkofel Crystalline Complex to be a fragment of the Ötztal Crystalline Complex, which has been thrusted onto the Innsbruck Quartz Phyllite after the peak of Late Cretaceous metamorphism.

South of Matrei (Fig. 1), the footwall of the Brenner Fault Zone forms the Tauern Window, which was exhumed during movement on the Brenner Fault Zone from depths corresponding to amphibolite facies metamorphic conditions in the last ca. $20 \mathrm{Ma}$ (Behrmann 1988; Selverstone 1988; Fügenschuh et al. 1997). It follows that the hanging wall in this region was already at temperatures below those necessary for annealing of apatite fission tracks (ca. $90-110{ }^{\circ} \mathrm{C}$ ) and therefore brittle throughout the Brenner Fault Zone history. In contrast, the immediate footwall of the Brenner Fault Zone involved a transition from a broad zone of ductile mylonites to more localized shearing and eventually to movement on a discrete brittle detachment during exhumation and cooling (Fügenschuh et al. 1997).
Unfortunately, no preserved clay fault gouge has yet been found associated with the Brenner Fault Zone detachment at the western end of the Tauern Window, although the clear topographic expression (a well-developed dip-slope and valley incision) certainly suggests that it is marked by a narrow zone of weaker material.

The hanging wall of the Silltal-Brenner Fault Zone consists of the Ötztal Crystalline Complex overlain by parautochtonous "Brenner Mesozoic" (meta-) sediments and the allochthonous Steinach and Blaser "nappes". Metamorphism in the Ötztal Crystalline Complex and Brenner Mesozoic increases progressively from lowermost greenschist in the north to amphibolite facies in the south (Frank et al. 1987; Purtscheller et al. 1987; Fügenschuh et al. 2000). Mineral ages reflect this, with white mica ${ }^{40} \mathrm{Ar} /{ }^{39} \mathrm{Ar}$ ages in the north still retaining pre-Alpine ages of ca. $270 \mathrm{Ma}$ whereas in the south they have been reset to Cretaceous ages of around $90 \mathrm{Ma}$ (Fig. 2; Rockenschaub et al. 2003). The anchimetamorphic Steinach and Blaser "nappes" (Teichmüller and Teichmüller 1978) are allochthons transported to the ESE on low-angle normal detachments during exhumation at the end of the Cretaceous (Fügenschuh et al. 2000) and preserve pre-Alpine white mica ${ }^{40} \mathrm{Ar} /{ }^{39} \mathrm{Ar}$ ages (Rockenschaub et al. 2003). In the area of the hanging wall shown in Fig. 2, zircon fission track ages range from 55 to $85 \mathrm{Ma}$ and apatite fission track ages from 22 to 54 Ma (Fügenschuh 1995; Fügenschuh et al. 2000).

\section{Sample location and description}

Clay-rich samples from the Silltal Fault were collected from in and around the Stephansbrücke clay pit (location A on Fig. 1) and from two other locations around $8 \mathrm{~km}$ to the SSE, north of Matrei (locations B and C on Fig. 1). In total six gouge samples were investigated: four samples from Stephansbrücke (SB1, SB2, SB3, SB4) and one sample each from locations B (BF1) and C (BF2) near Matrei.

Clay from the quarry of Stephansbrücke was worked in former times as a raw material for ceramics, bricks and roofing tiles and was of excellent quality and plasticity due to the high clay mineral content (up to $80 \%$ according to Czurda and Bertha 1984). Blaas (1885, p. 101) was the first to describe the blue-grey clay geologically, recognizing the sharp contact to the sand and gravel of the overlying glacial terrace sediments and the more gradational contact to the underlying solid rock of the Innsbruck Quartz Phyllite. He interpreted this transition, with common clasts of veinquartz from the underlying Quartz Phyllite (Fig. 3; cf. Figure 3C in Reiter et al. 2005), as a clear example of a ground moraine reworking components from below. The blue-grey foliated clay is $>15 \mathrm{~m}$ thick (Paschinger 1953), 


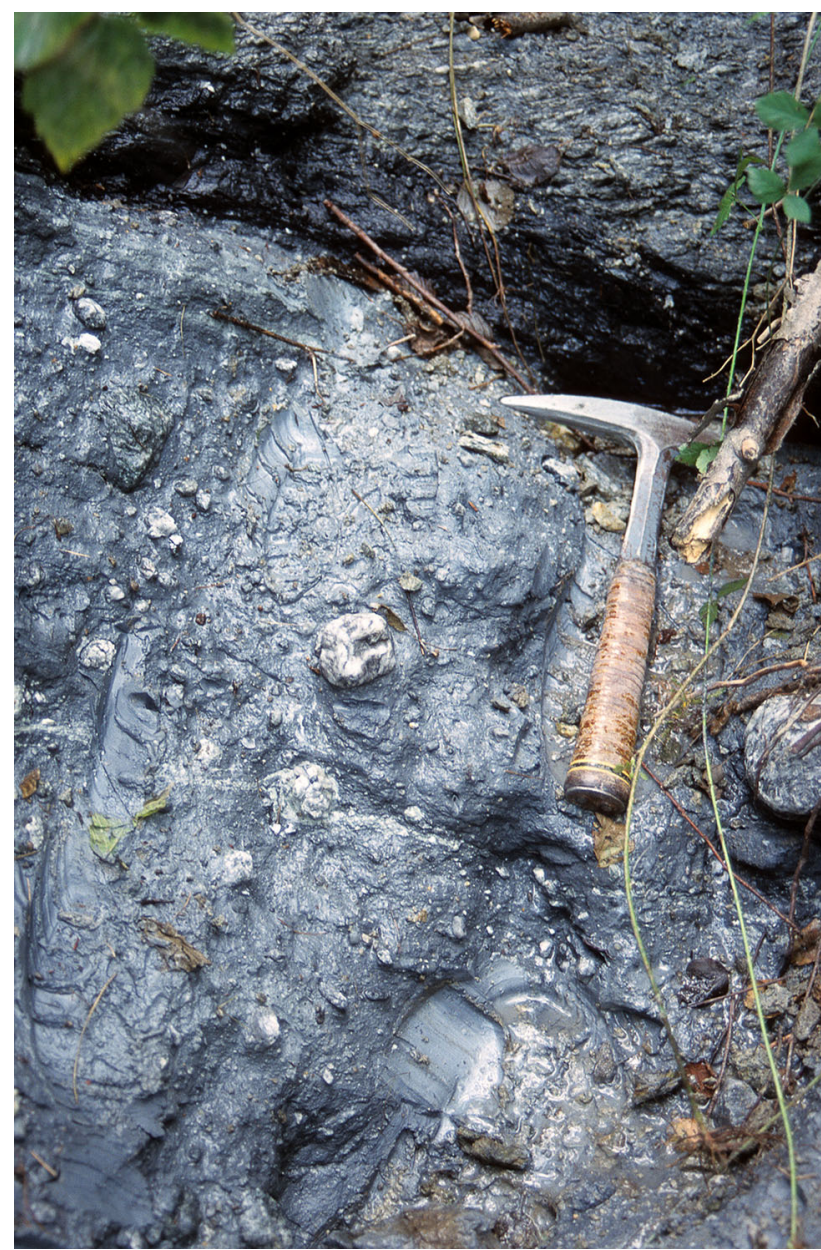

Fig. 3 Photograph looking west of the shallow trench in the clay gouge from which sample SB3 was collected. Note the white quartz clasts, which are typical of the footwall Innsbruck Quartz Phyllite

with common vein-quartz clasts covering a wide range of sizes up to several centimetres (Fig. 3). Below it is moreor-less contiguous with the Innsbruck Quartz Phyllite and above it is overlain by ca. $200 \mathrm{~m}$ of Quaternary Inntal terrace sediments, with a sharp contact to the clay (Paschinger 1953). The nearest outcrops of metamorphic rocks above the clay quarry are mica schists of the Ötztal Crystalline Complex (Decker et al. 2009). Although the common vein-quartz clasts already convinced Blaas (1885) and von Klebelsberg (1935) that the clay derived directly from the Innsbruck Quartz Phyllite below, it was Paschinger (1953) and Schmidegg (1953) who were the first to propose that the clay developed as the result of movement on a major fault zone. At the time, the grain size reduction was assigned to "mylonitization", whereas now we would refer to the process they envisaged as cataclasis. Paschinger (1953) considered the movements to reflect (west-directed) overthrusting of the Ötztal nappe onto the Innsbruck Quartz Phyllite, in a similar manner to what has been more recently proposed by Rockenschaub et al. (2003) and Piber et al. (2008) for the klippe of Patscherkofel Crystalline Complex overlying the Innsbruck Quartz Phyllite east of Stephansbrücke (Fig. 1). Von Klebelsberg (1935), Schmidegg (1953), and Horninger and Weiss (1980) all proposed that clay formation could be totally or partly due to alteration of earlier "mylonite" by meteoric water derived from the overlying glacial terrace sediments.

From the Stephansbrücke locality, samples SB1 and SB2 were collected within ca. $1 \mathrm{~m}$ of each other on the western rim of the old clay pit (now filled as a waste disposal site), sample SB3 was collected from a trench dug a few metres to the west (Fig. 3) and sample SB4 was taken from a steep wall ca. $20 \mathrm{~m}$ further southwest. This outcrop shows a well-developed foliation and $\mathrm{S}-\mathrm{C}-\mathrm{C}^{\prime}$ (Berthé et al. 1979) or "shear band" structure, indicating normal (topdown-to-W) sense of movement (Fig. 3a, b in Reiter et al. 2005).

For the Matrei samples further SSE, BF1 was collected a few metres below the surface in a small tunnel on the west side of the main Brenner freeway (Location B, Fig. 1). Here, the fault gouge is derived from reworked Ötztal Crystalline Complex in the immediate hanging wall of the Silltal Fault. BF2 (Location C, Fig. 1) came from a drainage tunnel below the Brenner freeway, some $30 \mathrm{~m}$ below the surface, and is situated in the footwall within the Reckner nappe (Fig. 1).

Different clay-size fault gouge fractions ranging from $<0.1$ to $6-10 \mu \mathrm{m}$ were analysed for their hydrogen isotope ratios $(\delta \mathrm{D})$, in particular to assess the possible influence of meteoric water during formation of the clay-size fractions. The $\delta \mathrm{D}$ of undeformed and recrystallized phyllosilicates sampled through the entire crustal section affected by Brenner Fault Zone deformation were also investigated, with the aim of constraining the pathway of fluid infiltration both along and across the detachment system. Rock samples containing white mica, biotite and chlorite were collected from both the brittle hanging wall and the mylonitic footwall of the Brenner Fault Zone at three different localities near Steinach, Gries and close to the Brenner Pass (Fig. 1). Samples were taken from immediately adjacent to the Brenner Fault Zone detachment and from up to ca. $660 \mathrm{~m}$ into the hanging wall and up to ca. $1 \mathrm{~km}$ into the footwall. All the hanging wall outcrops considered in this study have been affected by intense brittle deformation and the chosen samples were essentially rich in chlorite. Rock samples collected within the footwall were strongly ductilely deformed with a sense-of-shear (top-down-to-W) consistent with Brenner Fault Zone movement, as was especially clear for the mica-schists and calc-schists. The phyllosilicate grains separated for hydrogen isotope analysis are generally recrystallized. 


\section{Methods}

\subsection{Sample preparation}

The procedures applied in this study are based on Zwingmann and Mancktelow (2004) and Zwingmann et al. (2010a). Approximately $200 \mathrm{~g}$ of fresh gouge and cataclastically ground rock material was collected from each sample site. Samples were gently disaggregated using a repetitive freezing and heating technique to avoid artificial reduction of rock components with K-bearing minerals, such as micas or K-feldspars (Liewig et al. 1987). Grain size fractions $<2,2-6$ and $6-10 \mu \mathrm{m}$ were separated in distilled water according to Stoke's law and $<0.4$ and $<0.1 \mu \mathrm{m}$ were separated using a high-speed centrifuge. For "whole-rock gouge" (WR) analysis a small amount of sample material was crushed in an agate mortar by hand. Samples were characterized by X-ray diffraction (XRD) (normal and glycolated runs), environmental scanning electron microscopy (ESEM) on original wet gouge material, and transmission electron microscopy (TEM).

\subsection{Mineralogy}

The mineralogy of the size fractions was determined by XRD on air-dried and glycolated samples following the approach outlined in Moore and Reynolds (1997). For clay polytype investigations the samples were lightly pressed into shallow stainless steel holders for XRD analysis. Oriented samples were prepared by dispersing approximately $40 \mathrm{mg}$ of material using ultrasonic agitation in approximately $5 \mathrm{ml}$ of deionised water. The slurries were deposited under suction onto $0.22 \mu \mathrm{m}$ Duropore $(C)$ filter membranes and then saturated with magnesium twice using $1 \mathrm{M} \mathrm{MgCl}_{2}$. The films were washed five times with deionised water and then five drops of glycerol added and gently spread over the entire clay surface. The samples remained on the vacuum manifold until all traces of liquid glycerol were gone. The oriented samples were placed onto absorbent paper towels to remove excess glycerol on the backs of the samples before mounting onto $25 \mathrm{~mm}$ aluminium discs with double sided tape. XRD patterns were recorded with a PANalytical X'Pert Pro microprocessor-controlled diffractometer using Fe filtered $\mathrm{Co} \mathrm{K} \alpha$ radiation, $0.25^{\circ}$ divergence slit, $0.50^{\circ}$ anti-scatter slit and X'Celerator fast Si strip detector. The diffraction patterns were recorded in steps of $0.016^{\circ} 2 \theta$ with a 1 s counting time per step, and logged to data files on a PC for analysis using HighScore Plus and CSIRO XPLOT software.

\subsection{Electron microscopy}

Freshly broken surfaces of moist gouge sample chips were examined by ESEM using a Zeiss EVO equipped with an energy dispersive system X-ray analyzer (EDS). Transmission electron microscopy (TEM) was used to identify and distinguish possible authigenic clays from finely ground protolith micas, feldspars and other contaminants, allowing the detection of traces of contaminant phases below the XRD detection limit. To this end, a JEOL 2010 TEM $(200 \mathrm{kV})$ was used for detailed, grain-by-grain morphological characterization of selected $<0.1 \mu \mathrm{m}$ clay fractions. Samples were prepared by placing one drop of clay solution on a microcarbon grid film and drying under air. The chemical composition of individual particles was investigated by an attached EDS system.

\section{4 $\mathrm{K}-$ Ar dating}

The K-Ar dating technique follows standard methods described in detail by Dalrymple and Lanphere (1969). K content was determined by atomic absorption. The pooled error of duplicate $\mathrm{K}$ determinations on several samples and standards is better than $2.0 \%$. Ar isotopic determinations were performed using a procedure similar to that described by Bonhomme et al. (1975). Samples were pre-heated under vacuum at $80{ }^{\circ} \mathrm{C}$ for several hours to reduce the amount of atmospheric Ar adsorbed onto the mineral surfaces during sample preparation. Ar was extracted from the mineral fractions by fusing samples using a low blank resistance furnace within a vacuum line serviced by an online ${ }^{38} \mathrm{Ar}$ spike pipette. The ${ }^{38} \mathrm{Ar}$ spike was calibrated against GA1550 biotite (McDougall and Roksandic 1974). The isotopic composition of the spiked Ar was measured with an on-line VG3600 mass spectrometer via Faraday cup. The released gases were subjected to a two-stage purification procedure via $\mathrm{CuO}$ and $\mathrm{Ti}$ getters. Blanks for the extraction line and mass spectrometer were systematically determined and the mass discrimination factor was determined by airshots. About $25 \mathrm{mg}$ of sample material was required for Ar analyses. Due to the hygroscopic nature of clays, special care was taken in the preparation of both $\mathrm{K}$ and Ar sample splits. For Ar analysis by noble gas spectrometry, sample splits were loaded into clean Mo-foil (Goodfellow molybdenum foil, thickness $0.0125 \mathrm{~mm}$, purity $99.9 \%$ ), weighed and subsequently preheated to $80{ }^{\circ} \mathrm{C}$ overnight to remove moisture, and re-weighted using a Mettler AT20 balance. The measured dry weight was used in the $\mathrm{K}-\mathrm{Ar}$ age calculation. Samples were stored prior to loading into the Ar purification line in a desiccator. During the course of the study, 10 international standards comprising 6 HD-B1 (Hess and Lippolt 1994) and 4 GLO (Odin et al. 1982) were measured. Standard and airshot data are listed in the table of Online Resource 1. The error for Ar analyses is below $1 \%$ (Online Resource 1) and the ${ }^{40} \mathrm{Ar} /{ }^{36} \mathrm{Ar}$ value for airshots averaged $295.02 \pm 0.28$ $(\mathrm{n}=10) . \mathrm{K}-\mathrm{Ar}$ ages were calculated using ${ }^{40} \mathrm{~K}$ abundance 
and decay constants recommended by Steiger and Jäger (1977).

\subsection{Stable isotope geochemistry}

Micas (muscovite and biotite) and chlorite with a grain size of $600-250 \mu \mathrm{m}$ were selected for isotopic analysis by crushing, grinding, and hand picking of individual mineral grains. For the phyllosilicate samples from the country rocks, a sample weight of $1 \mathrm{mg}$ for chlorite and $2 \mathrm{mg}$ for micas was wrapped into silver foil and placed into a Hepurged autosampler. For the fine-grained clay separates, a sample weight of $1 \mathrm{mg}$ was wrapped into silver foil and dried overnight at $150{ }^{\circ} \mathrm{C}$ in a stainless steel tray. Samples were rapidly transferred to a zero-blank autosampler in the stainless steel tray and the autosampler was immediately purged with Helium gas to avoid re-hydration with ambient air moisture. $\delta \mathrm{D}$ values were measured at Leibniz Universität Hannover using a Thermo Electron delta V advantage mass spectrometer in continuous flow mode coupled to a high temperature conversion elemental analyser (TC-EA). Clay samples BF1 and BF2 were analysed following the same procedure at Goethe University Frankfurt on a ThermoFinnigan MAT 253 mass spectrometer. In-house and three international standards were run with the samples and yielded $\delta \mathrm{D}=-65.5 \%$ $(\mathrm{n}=21 ; \quad$ NBS30 biotite), $\delta \mathrm{D}=-119.4 \% \quad \% \quad(\mathrm{n}=21$; NBS22 oil), and $\delta \mathrm{D}=-102.7 \%$ o $(\mathrm{n}=21$; $\mathrm{CH} 7$ polyethylene foil). Standards were run in-line with unknowns and reproduced with an error below $\pm 2 \%$. All $\delta \mathrm{D}$ values are reported relative to standard mean ocean water (VSMOW).

\section{Results}

\subsection{Mineralogy and chemical composition of the dated fault gouge samples}

The modal mineral compositions determined by X-ray Diffraction (XRD) of the clay size fractions dated in this study are listed in Table 1 . The striking observation is that there is no detectable $1 \mathrm{M}$ (including $1 \mathrm{M}_{\mathrm{d}}$ ) polytype illite or mixed-layer illite/smectite (I/S) in any of the fault gouge samples: only $2 \mathrm{M}_{1}$ illite/muscovite and chlorite are observed in all the samples, with smectite also present in samples from the Stephansbrücke area. This is unusual because a progression from smectite to random I/S to ordered I/S to illite is typically observed with increasing depth of burial and temperature, corresponding to the transition from diagenesis to anchimetamorphism to epizone (greenschist) metamorphism (e.g. Kisch 1983; Hunziker et al. 1986; Merriman and Frey 1999; Wilson
2013). Correspondingly, on a prograde path illite should evolve through an overlapping sequence of polytypes with increasing temperature, from $1 \mathrm{M}_{\mathrm{d}}$ to $1 \mathrm{M}$ to $2 \mathrm{M}_{1}$ (Yoder and Eugster 1955; Yoder 1957; Reynolds 1963; Velde 1965; Maxwell and Hower 1967; Merriman and Roberts 1985; Hunziker et al. 1986; Dalla Torre and Frey 1997; Wilson 2013). The gradational prograde transformation to $2 \mathrm{M}_{1}$ begins in the lowermost anchizone and is effectively completed by the transition to the epizone (Hunziker et al. 1986; cf. their Fig. 5), corresponding to a temperature range of ca. $200-300{ }^{\circ} \mathrm{C}$ (Merriman and Frey 1999). On the retrograde path, neocrystallization and recrystallization of clay due to cataclasis and fluid-rock interaction in an active brittle fault exhumed to the surface should produce the reverse sequence, although the reaction kinetics may be sluggish (Yoder and Eugster 1955; Yoder 1957). Most clay fault gouges are therefore a mixture of comminuted protolith ("detrital") clay/mica/chlorite and different authigenic clay-sized minerals and polytypes (Vrolijk and van der Pluijm 1999; Ylagan et al. 2002; Zwingmann et al. 2010a; Surace et al. 2011; Bense et al. 2014). However, this is not what is observed in Silltal Fault gouges. In all samples, higher temperature $2 \mathbf{M}_{1}$ illite/muscovite is the dominant clay mineral present and in the southern Matrei samples BF1 and BF2, it is the only clay mineral that occurs.

Muscovite and $2 \mathrm{M}_{1}$ illite are not distinguishable by $\mathrm{XRD}$ and the transition is anyway gradational. Both are dioctahedral micas but differ in their chemistry, with illite having lower $\mathrm{K}$ and correspondingly less $\mathrm{Al}$ and more $\mathrm{Si}$. In the "standard nomenclature" for micas, illite has the simplified (i.e. not considering possible $\mathrm{Fe}^{2+}$ or $\mathrm{Mg}^{2+}$ substitution, or vacancies) general formula $\mathrm{K}_{x} \mathrm{Al}_{2}\left(\mathrm{Al}_{x} \mathrm{Si}_{4-x}\right.$ $\mathrm{O}_{10}(\mathrm{OH})_{2}$, with $0.6<x<0.85$, whereas muscovite has $x>0.85$ and an idealized end-member composition when $x=1$ (Bailey 1984; Rieder et al. 1999). However, this "standard nomenclature" is not universally accepted, and the range assigned to illite has been extended by some authors to cover a significantly larger range of $0.31<x<0.89$ (Yates and Rosenberg 1998), with the apparent end-member of the illite series regarded as having $x=0.88 \pm 0.01$ interlayer cations per half cell (Yates and Rosenberg 1997, 1998; Ylagan et al. 2000; Rosenberg 2002).

It follows that the most characteristic chemical difference between $2 \mathrm{M}_{1}$ illite and $2 \mathrm{M}_{1}$ muscovite is that illite is deficient in $\mathrm{K}$ compared to muscovite. Since $2 \mathrm{M}_{1}$ polytype illite/muscovite is effectively the only K-bearing mineral in the separated and dated clay fractions, it is possible to estimate the $\mathrm{K}$ content of this illite/muscovite component by plotting the amount of the polytype present in the samples (as determined by XRD analysis; Table 1) against the measured bulk \% $\mathrm{K}$ in the same samples (as determined 
Table 1 Quantitative determination of mineralogy of the size fractions determined by X-Ray diffraction (XRD) on air-dried and glycolated samples

\begin{tabular}{|c|c|c|c|c|c|c|c|}
\hline Sample & Quartz & Plagioclase & Calcite & Chlorite & Smectite & Illite/Mica $2 \mathrm{M}_{1}$ & Paragonite $2 \mathrm{M}_{1}$ \\
\hline $\mathrm{SB} 2<0.4 \mu \mathrm{m}$ & & & & 5 & 35 & 60 & \\
\hline $\mathrm{SB} 2<2 \mu \mathrm{m}$ & $<1$ & & & 9 & 32 & 59 & \\
\hline SB2 2-6 $\mu \mathrm{m}$ & 2 & & & 9 & 34 & 55 & \\
\hline SB2 $6-10 \mu \mathrm{m}$ & 2 & & & 10 & 34 & 54 & \\
\hline SB3 $<0.4 \mu \mathrm{m}$ & & & & 3 & 34 & 63 & \\
\hline $\mathrm{SB} 3<2 \mu \mathrm{m}$ & & & & 7 & 17 & 75 & 1 \\
\hline SB3 2-6 $\mu \mathrm{m}$ & 4 & & & 19 & 13 & 60 & 4 \\
\hline SB3 $6-10 \mu \mathrm{m}$ & 9 & & & 34 & 5 & 47 & 5 \\
\hline $\mathrm{SB} 4<0.1 \mu \mathrm{m}$ & & & & 2 & 9 & 88 & \\
\hline SB4 $<0.4 \mu \mathrm{m}$ & & & & 6 & 33 & 61 & \\
\hline $\mathrm{SB} 4<2 \mu \mathrm{m}$ & & & & 6 & 32 & 62 & \\
\hline SB4 2-6 $\mu \mathrm{m}$ & 2 & & & 11 & 27 & 60 & $<1$ \\
\hline SB4 6-10 $\mu \mathrm{m}$ & 4 & & & 20 & 21 & 53 & 2 \\
\hline $\mathrm{BF} 1<0.1 \mu \mathrm{m}$ & & & & 12 & & 88 & \\
\hline $\mathrm{BF} 1<0.4 \mu \mathrm{m}$ & & & & 15 & & 85 & \\
\hline $\mathrm{BF} 1<2 \mu \mathrm{m}$ & 2 & & & 17 & & 81 & \\
\hline BF1 $2-6 \mu \mathrm{m}$ & 5 & 2 & & 17 & & 76 & \\
\hline BF1 6-10 $\mu \mathrm{m}$ & 10 & 2 & & 11 & & 76 & \\
\hline BF1 WR & 24 & 5 & 2 & 9 & & 60 & \\
\hline $\mathrm{BF} 2<0.1 \mu \mathrm{m}$ & & & & 11 & & 89 & \\
\hline $\mathrm{BF} 2<0.4 \mu \mathrm{m}$ & & & & 10 & & 90 & \\
\hline $\mathrm{BF} 2<2 \mu \mathrm{m}$ & 2 & & & 23 & & 76 & \\
\hline BF2 2-6 $\mu \mathrm{m}$ & 2 & & & 17 & & 81 & \\
\hline BF2 $6-10 \mu \mathrm{m}$ & 6 & & & 17 & & 76 & \\
\hline BF2 WR & 33 & 6 & & 8 & & 52 & \\
\hline
\end{tabular}

The potential error on the estimates is taken as $\pm 5 \%$. WR ("whole rock") refers to the field sample as collected, without size fraction separation

by $\mathrm{K}-\mathrm{Ar}$ dating; Table 2). This should give a mixing line, with the mineral composition corresponding to $100 \%$ $2 \mathrm{M}_{1}$. The result is shown in Fig. 4, with $\mathrm{K}$ content presented as wt $\% \mathrm{~K}_{2} \mathrm{O}$. For comparison, the plot also shows the range of wt $\% \mathrm{~K}_{2} \mathrm{O}$ measured by electron microprobe on samples of metamorphic footwall muscovites from the Innsbruck Quartz Phyllite (Piber and Tropper 2007) and from the Patscherkofel Crystalline Complex (Piber et al. 2008), which show the same range in composition. In addition, a single representative analysis for illite from the online resource www.webmineral.com is shown. Figure 4 indicates that the composition of $2 \mathrm{M}_{1}$ polytype in most samples from the Stephansbrücke locality is identical to that of the muscovite from the metamorphic rocks in the footwall. Only the two samples richest in $2 \mathrm{M}_{1}$ component (SB3 $<2 \mu \mathrm{m}$ and SB4 $<0.1 \mu \mathrm{m}$ ) are deficient in $\mathrm{K}$ and plot within the illite field. In contrast, the samples from the southern Matrei localities are all K-deficient, with compositions typical of illite and distinctly different from the protolith muscovite compositions of the footwall Innsbruck Quartz Phyllite.

\subsection{SEM and TEM observations on clay morphology}

Under the ESEM, original wet "whole rock" samples show large, 10-20 $\mu \mathrm{m}$ sized, irregular grains surrounded by a finer grained matrix, both of which appear to have developed by mechanical comminution (Fig. 5a), rather than the well-crystallized fibrous, lath-shaped or platelet forms more typical of authigenic clay minerals (Inoue et al. 1988; Clauer and Chaudhuri 1995; Pevear 1999). However, TEM investigations of selected $<0.1 \mu$ m clay fractions show that the finest separated clay mineral particles have a relatively equant platelet form, generally with rather irregular diffuse boundaries but also with some straight, idiomorphic, euhedral edges (arrowed in Fig. 5b). The particles investigated by both SEM and TEM contain $\mathrm{Al}, \mathrm{Si}, \mathrm{O}, \mathrm{K}$ and $\mathrm{Fe}$ as determined by EDS, so that these characteristic forms must correspond to the $2 \mathrm{M}_{1}$ illite/muscovite component identified by XRD.

Previous experimental and field studies show that there is a gradual change from more fibrous and lathshaped forms to hexagonal-shaped platelets with 
Table 2 Sample ID, location as GPS coordinates, size fractions and K-Ar data

\begin{tabular}{|c|c|c|c|c|c|c|c|}
\hline Sample ID & $\begin{array}{l}\text { Coordinates UTM } \\
\text { WGS } 84 \text { Zone } 32 \mathrm{~N}\end{array}$ & ID size fraction & $\mathrm{K}(\%)$ & $\operatorname{Rad} 40 \mathrm{Ar}(\mathrm{mol} / \mathrm{g})$ & $\operatorname{Rad} 40 \operatorname{Ar}(\%)$ & Age (Ma) & Error $(\mathrm{Ma})$ \\
\hline SB1 & $680677 / 5231327$ & $292<0.4 \mu \mathrm{m}$ & 4.37 & $3.914 \mathrm{E}-10$ & 74.16 & 50.9 & 1.0 \\
\hline SB1 & & $292<2 \mu \mathrm{m}$ & 4.43 & $5.822 \mathrm{E}-10$ & 91.23 & 74.2 & 1.5 \\
\hline SB1 & & $2922-6 \mu \mathrm{m}$ & 4.25 & $5.998 \mathrm{E}-10$ & 91.33 & 79.6 & 1.6 \\
\hline SB2 & $680677 / 5231327$ & $621<0.4 \mu \mathrm{m}$ & 4.80 & $4.251 \mathrm{E}-10$ & 67.81 & 50.3 & 1.1 \\
\hline SB2 & & $621<2 \mu \mathrm{m}$ & 4.69 & $5.092 \mathrm{E}-10$ & 75.00 & 61.5 & 1.2 \\
\hline SB2 & & $6212-6 \mu \mathrm{m}$ & 4.52 & $5.052 \mathrm{E}-10$ & 78.08 & 63.3 & 1.3 \\
\hline SB2 & & $6216-10 \mu \mathrm{m}$ & 4.33 & $5.031 \mathrm{E}-10$ & 81.67 & 65.8 & 1.4 \\
\hline SB2 & & $621 \mathrm{WR}$ & 3.42 & $4.020 \mathrm{E}-10$ & 86.85 & 66.5 & 1.4 \\
\hline SB3 & $680672 / 5231324$ & $622<0.4 \mu \mathrm{m}$ & 5.11 & $4.744 \mathrm{E}-10$ & 61.30 & 52.8 & 1.1 \\
\hline SB3 & & $622<2 \mu \mathrm{m}$ & 5.23 & $6.854 \mathrm{E}-10$ & 76.68 & 74.0 & 1.5 \\
\hline SB3 & & $6222-6 \mu \mathrm{m}$ & 4.94 & $7.995 \mathrm{E}-10$ & 88.21 & 91.0 & 1.8 \\
\hline SB3 & & $6226-10 \mu \mathrm{m}$ & 3.82 & $7.860 \mathrm{E}-10$ & 96.90 & 114.9 & 2.4 \\
\hline SB3 & & $622 \mathrm{WR}$ & 3.41 & $6.032 \mathrm{E}-10$ & 92.94 & 99.2 & 2.0 \\
\hline SB4 & $680671 / 5231296$ & $623<0.1 \mu \mathrm{m}$ & 4.87 & $3.065 \mathrm{E}-10$ & 52.76 & 35.9 & 0.8 \\
\hline SB4 & & $623<0.4 \mu \mathrm{m}$ & 5.09 & $5.003 \mathrm{E}-10$ & 70.99 & 55.8 & 1.2 \\
\hline SB4 & & $623<2 \mu \mathrm{m}$ & 5.23 & $6.521 \mathrm{E}-10$ & 79.97 & 70.5 & 1.4 \\
\hline SB4 & & $6232-6 \mu \mathrm{m}$ & 5.16 & $7.015 \mathrm{E}-10$ & 85.36 & 76.7 & 1.5 \\
\hline SB4 & & $6236-10 \mu \mathrm{m}$ & 4.69 & $6.9815 \mathrm{E}-10$ & 87.36 & 83.8 & 1.7 \\
\hline SB4 & & $623 \mathrm{WR}$ & 3.35 & $4.602 \mathrm{E}-10$ & 88.18 & 77.5 & 1.6 \\
\hline BF1 & $685134 / 5225168$ & $1301<0.1 \mu \mathrm{m}$ & 4.88 & $1.0426 \mathrm{E}-10$ & 42.50 & 12.3 & 0.4 \\
\hline BF1 & & $1301<0.4 \mu \mathrm{m}$ & 4.99 & $1.4696 \mathrm{E}-10$ & 54.81 & 16.9 & 0.4 \\
\hline BF1 & & $1301<2 \mu \mathrm{m}$ & 4.87 & $2.1283 \mathrm{E}-10$ & 69.89 & 25.0 & 0.5 \\
\hline BF1 & & $13012-6 \mu \mathrm{m}$ & 4.48 & $2.0177 \mathrm{E}-10$ & 71.78 & 25.8 & 0.5 \\
\hline BF1 & & $13016-10 \mu \mathrm{m}$ & 4.33 & $1.8863 \mathrm{E}-10$ & 72.72 & 24.9 & 0.6 \\
\hline BF1 & & $1301 \mathrm{WR}$ & 3.12 & $2.4632 \mathrm{E}-10$ & 83.02 & 45.0 & 1.0 \\
\hline BF2 & 6854725224161 & $1302<0.1 \mu \mathrm{m}$ & 5.02 & $1.5471 \mathrm{E}-10$ & 52.19 & 17.7 & 0.4 \\
\hline BF2 & & $1302<0.4 \mu \mathrm{m}$ & 4.89 & $2.5595 \mathrm{E}-10$ & 69.41 & 29.9 & 0.6 \\
\hline BF2 & & $1302<2 \mu \mathrm{m}$ & 5.00 & $4.1719 \mathrm{E}-10$ & 82.39 & 47.5 & 1.0 \\
\hline BF2 & & $13022-6 \mu \mathrm{m}$ & 4.79 & $4.5898 \mathrm{E}-10$ & 86.88 & 54.4 & 1.1 \\
\hline BF2 & & $13026-10 \mu \mathrm{m}$ & 4.67 & $4.4493 \mathrm{E}-10$ & 88.87 & 54.1 & 1.1 \\
\hline $\mathrm{BF} 2$ & & $1302 \mathrm{WR}$ & 3.04 & $2.9465 \mathrm{E}-10$ & 85.41 & 55.0 & 1.2 \\
\hline
\end{tabular}

Note that Sample ID (SB and BF) refers to field samples, whereas ID numbers of the size fractions are those assigned by CSIRO, Earth Science and Resource Engineering, Kensington, Western Australia during separation and analysis and are the ones used in their internal database. Note also that the analysis of $\mathrm{K}$ is given as $\% \mathrm{~K}$, and not $\% \mathrm{~K}_{2} \mathrm{O}$ (e.g. Clauer 2013)

evolution to the higher temperature $2 \mathrm{M}_{1}$ polytype (Inoue et al. 1988; Clauer and Chaudhuri 1995; Bauer et al. 2000; Clauer et al. 2014). Schleicher et al. (2006) also observed that, in a hydrothermally altered granite, authigenic $2 \mathrm{M}_{1}$ illite in vein fillings had a platy pseudohexagonal form, whereas $1 \mathrm{M}$ illite filling pores was fibrous. The morphology of the finest clay particles (Fig. 5b) is therefore typical of the higher temperature $2 \mathrm{M}_{1}$ polytype, confirming the quantitative XRD determinations showing that this is the only illite polytype present. The preserved idiomorphic forms and the K-deficient chemistry of this sample size fraction (BF2 $<0.1 \mu \mathrm{m}$; see Fig. 4) is direct evidence for neocrystallization of fine $2 \mathrm{M}_{1}$ illite. The diffuse, irregular edges of many grains are more characteristic of protolith or "detrital" grains (e.g. Clauer and Chaudhuri 1995), but authigenic illite grains affected by ongoing fault movement would also be deformed and their edges may become irregular. The SEM and TEM observations therefore confirm the clay mineralogy and indicate that at least some of the finest clay fraction in the fault gouge is authigenic $2 \mathrm{M}_{1}$ illite. However, an additional component of comminuted protolith ("detrital") muscovite (perhaps corresponding to the grains with irregular diffuse boundaries) cannot be unequivocally excluded on the basis of the TEM observations alone. 


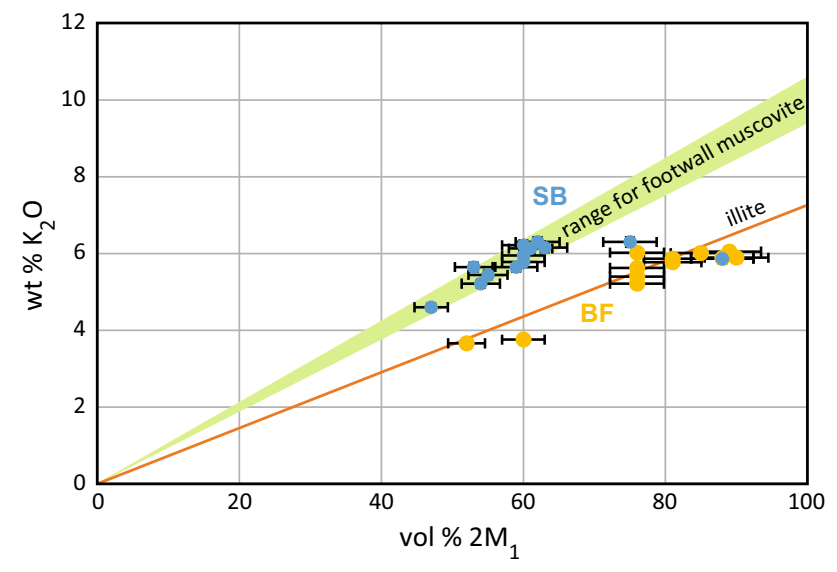

Fig. 4 Plot of analysed wt $\% \mathrm{~K}_{2} \mathrm{O}$ (recalculated from $\% \mathrm{~K}$ in Table 2, error bars $\pm 2 \%$, hardly visible on the plot) versus vol\% $2 \mathrm{M}_{1}$ (error bars $\pm 5 \%$ ) for all size fractions for which data is available (Table 1). The range of $\mathrm{wt} \% \mathrm{~K}_{2} \mathrm{O}$ in representative muscovite analyses from the Innsbruck Quartz Phyllite in the immediate footwall is also given (9.39-10.6 wt $\% \mathrm{~K}_{2} \mathrm{O}$; data from Piber and Tropper 2007), as well as a representative illite analysis $\left(7.26 \mathrm{wt} \% \mathrm{~K}_{2} \mathrm{O}\right.$; Mineralogy Database of http://webmineral.com/). Data table for the plot is available in Online Resource 2

\section{$5.3 \mathrm{~K}-$ Ar dating}

In total $32 \mathrm{~K}-\mathrm{Ar}$ analyses comprising 5 whole rock splits and 27 clay fractions from $<0.1$ to $6-10 \mu \mathrm{m}$ were obtained in this study (Table 2). The whole rock ages range from 45.0 to $99.2 \mathrm{Ma}$, whereas the clay fraction ages range from 12.3 to $114.9 \mathrm{Ma}$. For the clay-size fractions, there is a consistent decrease in age with decreasing grain size (Fig. 6). Ages for the Stephansbrücke samples range from 114.9 Ma (SB3, 6-10 $\mu \mathrm{m})$ to $35.9 \mathrm{Ma}(\mathrm{SB} 4,<0.1 \mu \mathrm{m})$ whereas for the Matrei samples further south the range extends down to significantly younger ages. The oldest ages for the Matrei samples are 54-55 Ma for the "whole rock sample" (WR) and 6-10 $\mu \mathrm{m}$ fraction of BF2 and the youngest age is $12.3 \mathrm{Ma}$ for the $<0.1 \mu \mathrm{m}$ fraction of $\mathrm{BF}$. It follows that the oldest ages of the Matrei samples (BF12) overlap with the youngest ages of the Stephansbrücke samples (SB1-4) but reach down to much younger (Neogene) ages for the finest fractions.

The overstepping age ranges for the different sample sites are also seen in Fig. 7, where the measured K-Ar ages for the size fractions less than $6 \mu \mathrm{m}$ are plotted against the interpreted $\mathrm{wt} \% \mathrm{~K}_{2} \mathrm{O}$ of the dated $2 \mathrm{M}_{1}$ polytype. However, Fig. 7 also shows that (1) there is a general trend (although with significant scatter) to younger ages with decreasing $\mathrm{K}$ content of the dated $2 \mathrm{M}_{1}$ polytype; (2) the samples with the oldest ages from the Stephansbrücke locality overlap in both composition and age with results from the Patscherkofel Crystalline Complex, which, from its location as a klippe on the Innsbruck Quartz Phyllite and from its
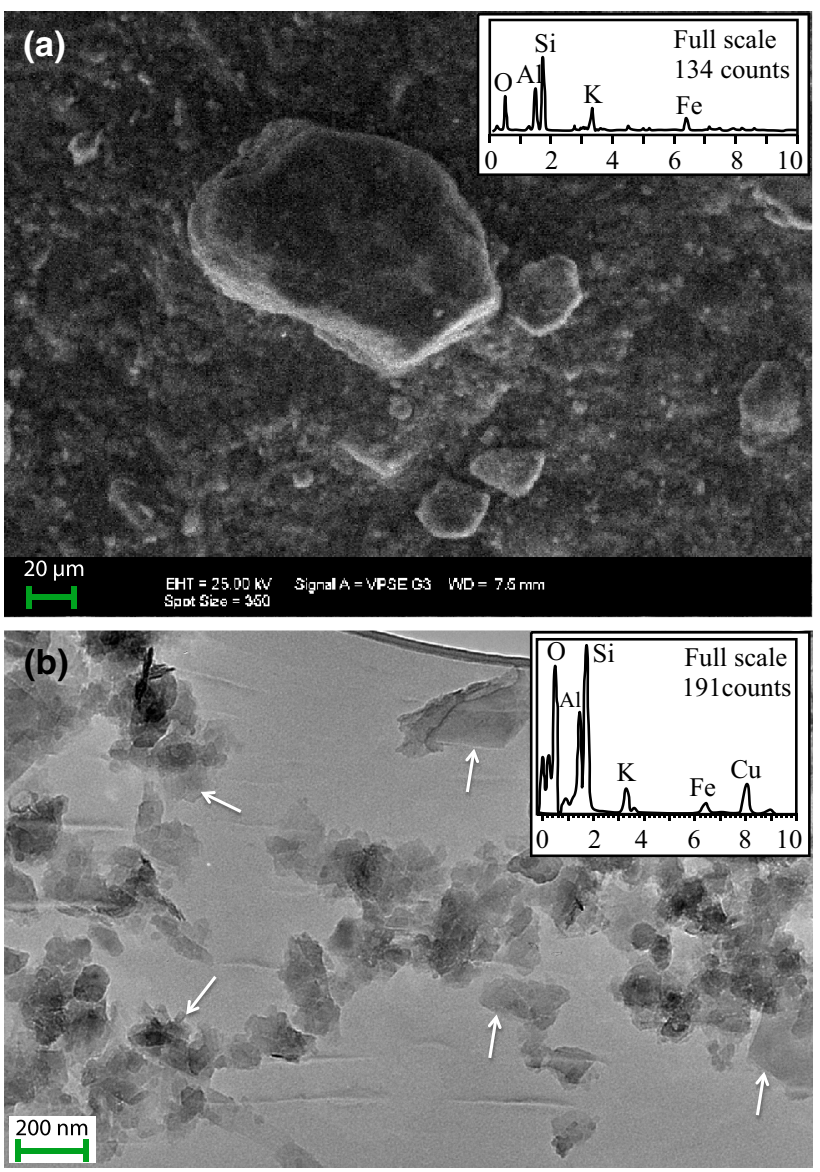

Fig. 5 Selected SEM and TEM images from Sample BF2, together with EDS scans indicating the qualitative chemical composition. These scans demonstrate that the grains analysed must correspond to the $2 \mathrm{M} 1$ illite/muscovite polytype, as it is the only K-bearing phase recognized in the quantitative XRD analysis. a SEM secondary electron image of the sampled "whole-rock gouge" as collected, showing large $(>20 \mu \mathrm{m})$ abraded grains in a finer grained matrix interpreted to have developed by comminution of larger muscovite protolith grains. b TEM image of the $<0.1 \mu \mathrm{m}$ size fraction, showing the irregular pseudohexagonal platelet morphology of grains typical of the $2 \mathrm{M}_{1}$ polytype. Many grains have diffuse, irregular boundaries, which are typical of abraded grains (either initial protolith or older authigenic grains), but some edges are straight (marked by arrows) and more indicative of authigenic illite

shallow dip to the SW, could be interpreted to intersect the Silltal-Brenner Fault Zone at the general level of the Stephansbrücke samples; and (3) the oldest $\mathrm{K}-\mathrm{Ar}$ ages from Stephansbrücke locality are much younger than the pre-Alpine ages obtained from muscovite ${ }^{40} \mathrm{Ar} /{ }^{39} \mathrm{Ar}$ in the Innsbruck Quartz Phyllite from the underlying footwall.

\subsection{Hydrogen isotope geochemistry}

White mica (ms), biotite (bt) and chlorite (chl) separates across the Brenner Fault Zone from within both the footwall and hanging wall yield $\delta \mathrm{D}$ values averaging $-59 \%$ (ms), $\quad-68 \%$ (bt) and $-64 \%$ (chl), respectively 


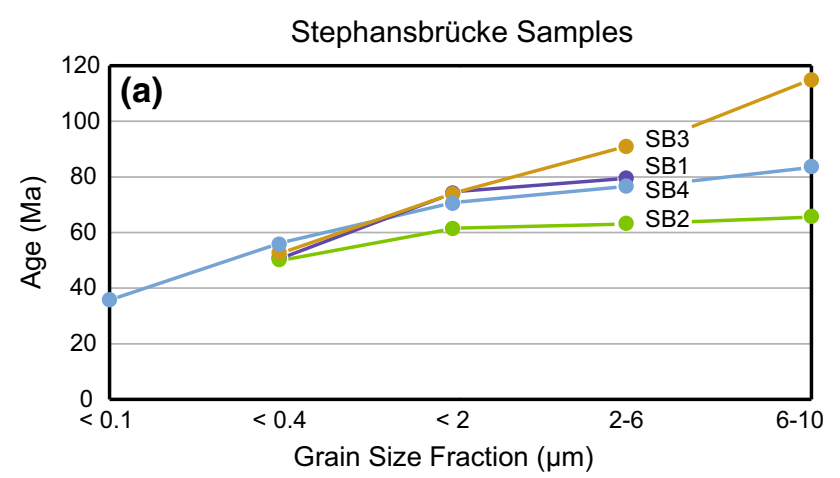

Southern Matrei Samples

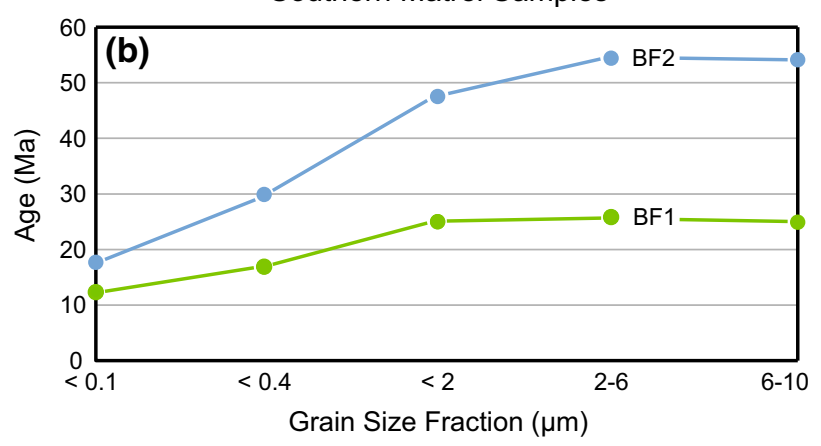

Fig. $6 \mathrm{~K}-\mathrm{Ar}$ age data plot versus size fractions for samples from a the Stephansbrücke area and $\mathbf{b}$ the more southerly Matrei area

(Table 3). In contrast, all clay gouge fractions have consistently lower $\delta \mathrm{D}$ values that range between -77 and $-108 \%$ (Table 4). Similarly to the K-Ar results, there is a clear correlation between $\delta \mathrm{D}$ values and grain size of the analysed fractions for both the Stephansbrïcke and the Matrei samples (Fig. 8), with $\delta \mathrm{D}$ values decreasing with grain size. It follows that there is also a direct correlation between $\mathrm{K}-\mathrm{Ar}$ age and $\delta \mathrm{D}$ values (Fig. 9). It is particularly striking that all four Stephansbrïcke samples, collected within a few tens of metres of each other from the same contiguous clay gouge location, plot on a very well-defined linear trend (Fig. 9a, $R^{2}=0.995$ ). The youngest Stephansbrücke sample (SB4 <0.1 $\mu \mathrm{m}$; Table 2) was not analysed for $\delta \mathrm{D}$, but extrapolation of the correlation line in Fig. 9a to its $\mathrm{K}-\mathrm{Ar}$ age of $35.9 \mathrm{Ma}$ would return a value of around $-111 \%$. The Matrei samples BF1 and BF2 plot on similar, but uniquely different, linear trends (Fig. 9b; BF1: $\left.R^{2}=0.969, \mathrm{BF} 2: R^{2}=0.935\right)$. The $\delta \mathrm{D}$ value for the youngest age from sample BF1 (12.3 Ma for BF1 $<0.1 \mu \mathrm{m}$; Table 2) is $-106 \%$ and extrapolation of the line for BF2 to the same age would give a value of about $-109 \%$. The finest grained fractions $(<0.1 \mu \mathrm{m})$ in all the samples from Stephansbrücke and near Matrei give both the youngest $\mathrm{K}-\mathrm{Ar}$ ages and the lowest $\delta \mathrm{D}$ values, in a quite limited range from ca. -106 to $-110 \%$ (within error of ca. $\pm 2 \%$ ).

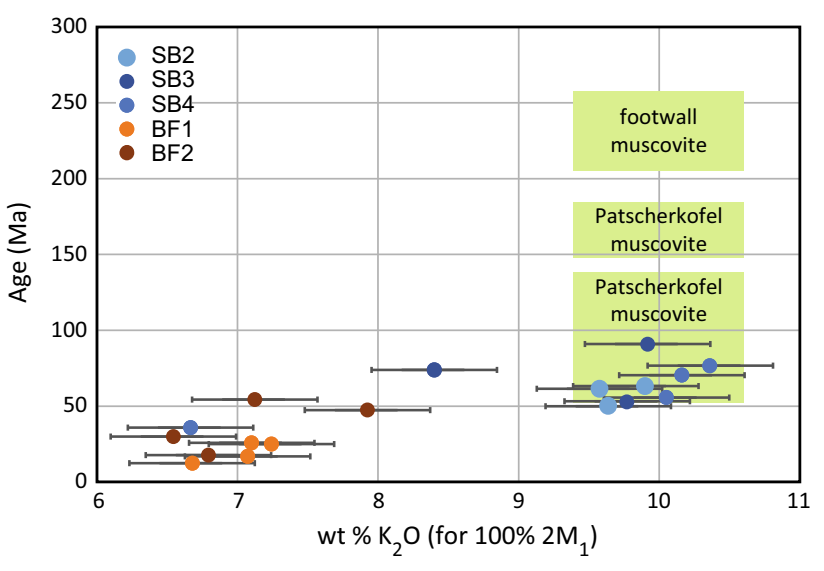

Fig. 7 Plot of $\mathrm{K}-\mathrm{Ar}$ age (Ma, error bars from Table 2 are not visible on the plot) against recalculated $\mathrm{wt} \% \mathrm{~K}_{2} \mathrm{O}$ extrapolated to $100 \% 2 \mathrm{M}_{1}$ component. Only the results for fractions finer than $6 \mu \mathrm{m}$ are plotted. Also shown for reference are the range of ${ }^{40} \mathrm{Ar} /{ }^{39} \mathrm{Ar}$ ages (Rockenschaub et al. 2003) and $\mathrm{wt} \% \mathrm{~K}_{2} \mathrm{O}$ for muscovites (Piber and Tropper 2007; Piber et al. 2008) determined from the Innsbruck Quartz Phyllite in the immediate footwall and the Patscherkofel Crystalline Complex klippe (Fig. 2). ${ }^{40} \mathrm{Ar} /{ }^{39} \mathrm{Ar}$ results for white mica from the Innsbruck Quartz Phyllite typically give Late Permian or Triassic to Jurassic ages (upper green box); the Patscherkofel Crystalline Complex shows a wide range but with two main peaks at around 149-180 Ma (middle green box) and 123-136 Ma (included in lower box), but one retrograde mylonitic gneiss from the base of the Complex has a white mica ${ }^{40} \mathrm{Ar} /{ }^{39} \mathrm{Ar}$ age spectrum with steps between 50 and $120 \mathrm{Ma}$ (included in lower box). Data table for the plot is available in Online Resource 3

The broad correlation of $\mathrm{K}-\mathrm{Ar}$ age with calculated wt $\%$ $\mathrm{K}_{2} \mathrm{O}$ for the $2 \mathrm{M}_{1}$ polytype illite/muscovite component (Fig. 7) together with the strong correlation of $\delta \mathrm{D}$ with age (Fig. 9) implies that there should also be a decrease in $\delta \mathrm{D}$ values with decreasing $\mathrm{wt} \% \mathrm{~K}_{2} \mathrm{O}$. However, as seen from the plot of Fig. 10, this correlation is weak, especially within the different size fractions from the northern and southern localities. In effect, Fig. 10 only highlights the distinction between the higher values of $\mathrm{wt} \% \mathrm{~K}_{2} \mathrm{O}$ in the $2 \mathrm{M}_{1}$ component for samples from the Stephansbrücke locality compared to the southerly Matrei samples, as already seen in Fig. 4, together with the tendency for the smallest size fractions in these southerly samples to return the most negative values of $\delta \mathrm{D}$.

\section{Discussion}

The major clay component in the fault gouge samples, as determined by quantitative XRD analysis, is $2 \mathrm{M}_{1}$ illite/muscovite, but there are variable amounts of smectite in the Stephansbrücke (SB) samples and secondary chlorite in all samples (Table 1). Chlorite is not a K-bearing mineral (e.g. see typical chemical analyses in Deer et al. 1992) and smectite in the Stephansbrücke samples is without 
Table 3 Hydrogen isotope data for muscovite, biotite and chlorite grains from sampled profiles across the Brenner Fault Zone, with distance to the fault given (positive values for the hanging wall, negative values for the footwall)

\begin{tabular}{|c|c|c|c|c|c|c|c|}
\hline Sample & $\begin{array}{l}\text { UTM coordinates } \\
\text { WGS } 84 \text { zone } 32 \mathrm{~N}\end{array}$ & $\begin{array}{l}\text { Structural } \\
\text { unit }\end{array}$ & Lithology & $\begin{array}{l}\delta \mathrm{D} M \mathrm{Ms} \\
(\%)\end{array}$ & $\begin{array}{l}\delta \mathrm{D} \mathrm{Bt} \\
(\%)\end{array}$ & $\begin{array}{l}\text { \&D Chl } \\
(\%)\end{array}$ & $\begin{array}{l}\text { Distance to } \\
\text { fault }(\mathrm{m})\end{array}$ \\
\hline \multicolumn{8}{|c|}{ Brenner Section } \\
\hline MC 921 & $687948 / 5210546$ & Hanging wall & Phyllite & -65 & & -64 & 624 \\
\hline MC 922 & $688654 / 5210451$ & Hanging wall & Phyllite & -60 & & -70 & 294 \\
\hline MC 918 & $689646 / 5209317$ & Hanging wall & Phyllite & -68 & & & 32 \\
\hline MC 920 & $689608 / 5209780$ & Hanging wall & Phyllite & -65 & & & 12 \\
\hline MC 910 & $689468 / 5210086$ & Footwall & Phyllite with sericite & -51 & & -62 & -31 \\
\hline MC 907 & $689427 / 5210187$ & Footwall & Phyllite with sericite & -56 & & & -41 \\
\hline MC 906 & $689511 / 5210208$ & Footwall & Phyllite with chlorite & & & -68 & -92 \\
\hline MC 924 & $689780 / 5210040$ & Footwall & Psammite & & & -63 & -136 \\
\hline MC 925 & $689840 / 5210029$ & Footwall & Schist with sericite & & & -63 & -156 \\
\hline MC 934 & $690186 / 5209267$ & Footwall & Calcschist with white mica & -52 & & & -233 \\
\hline MC 932 & $690261 / 5209269$ & Footwall & Calcschist with white mica & -60 & & & -271 \\
\hline MC 887 & $690588 / 5209535$ & Footwall & Calcschist with white mica & -59 & & & -448 \\
\hline MC 889 & $690626 / 5209517$ & Footwall & Micaschist with garnet & -53 & & -66 & -466 \\
\hline MC 897 & $691235 / 5208870$ & Footwall & Calcschist & & -73 & & -741 \\
\hline MC 893 & $691851 / 5208317$ & Footwall & Orthogneiss with biotite & & -62 & & -1062 \\
\hline MC 894 & $691915 / 5208267$ & Footwall & Orthogneiss with biotite & & -68 & & -1097 \\
\hline \multicolumn{8}{|c|}{ Gries section } \\
\hline MC 937 & $688168 / 5212007$ & Hanging wall & Dolomite with chlorite & -65 & & -66 & 314 \\
\hline MC 939 & $688168 / 5212007$ & Hanging wall & Dolomite with chlorite & & & -64 & 312 \\
\hline MC 942 & $688371 / 5212232$ & Hanging wall & Dolomite with chlorite & & & -61 & 178 \\
\hline \multicolumn{8}{|c|}{ Nösslach section } \\
\hline MC 883 & $687461 / 5216692$ & Hanging wall & Chlorite-rich layer in quartzite & & & -59 & 239 \\
\hline
\end{tabular}

discernible mixed-layers of illite and should also be effectively $\mathrm{K}$-free. The $\mathrm{K}-\mathrm{Ar}$ dates presented in Table 2 therefore only derive from the K-bearing $2 \mathrm{M}_{1}$ illite/muscovite component. However, there remains a correlation in the SB samples between the measured $\mathrm{K}-\mathrm{Ar}$ ages and both the modal \% smectite (Fig. 11a) and \% chlorite (Fig. 11b). Inspecting Table 1 reveals the reason for this observation: the modal $\%$ of these minerals is an effective proxy for the grain size of the dated fraction, with chlorite decreasing in abundance and smectite increasing in abundance as the grain size decreases, and in turn the $\mathrm{K}-\mathrm{Ar}$ age decreases with the grain size of different fractions separated from each sample (Table 2; Fig. 6). The indirect nature of this correlation is emphasized by the one clear outlier in Fig. 11a. There is apparently a lower limit to the grain size distribution of the smectite, because this finest-grained sample (SB4 $<0.1 \mu \mathrm{m}$ ) does not continue the trend of increasing smectite component: it has only $9 \%$ smectite, but returns the youngest age ( $35.9 \mathrm{Ma})$. The real correlation is therefore with grain size, as shown in Fig. 6, and not directly with modal \% smectite or chlorite.

Relatively pure smectite without mixed illite/smectite layers only develops at low temperatures, well below $\sim 80{ }^{\circ} \mathrm{C}$ (Pytte and Reynolds 1989; Huang et al. 1993) and, under these near-surface conditions, probably crystallized due to interaction of existing cataclastic fault gouge with meteoric water. It may even have developed at or very near the surface during glaciation and deposition of the overlying glacial moraine sediments, as was previously proposed for the development of clay in the Stephansbrücke location by von Klebelsberg (1935), Schmidegg (1953), and Horninger and Weiss (1980). If smectite formed near surface by interaction with meteoric water, the $\delta \mathrm{D}$ values of the smectite component should reflect this origin: increasing amounts of smectite in the SB samples should be reflected in increasingly negative $\delta \mathrm{D}$ values for the bulk grain-size fraction. There is indeed a broad trend, as shown in Fig. 11c, but it is much weaker than the correlation between age and $\delta \mathrm{D}$ (Fig. 9a). This strong correlation between age and $\delta \mathrm{D}$ is also seen in the southern Matrei samples (BF1 and BF2, Fig. 9b), where there is no smectite present. Again it appears that the observed trend in Fig. 11c actually reflects the grain size (for which the amount of smectite is a proxy), which in turn is reflected in the age and $\delta \mathrm{D}$, rather than a direct influence of the amount and isotopic composition of the smectite itself. 
Table 4 Hydrogen isotope data for dated clay size fraction separates

\begin{tabular}{|c|c|}
\hline Sample & $\delta \mathrm{D}(\%)$ \\
\hline $\mathrm{SB} 2<2 \mu \mathrm{m}$ & -95 \\
\hline SB2 $2-6 \mu \mathrm{m}$ & -93 \\
\hline $\mathrm{SB} 3<0.4 \mu \mathrm{m}$ & -101 \\
\hline $\mathrm{SB} 3<2 \mu \mathrm{m}$ & -87 \\
\hline SB3 $2-6 \mu \mathrm{m}$ & -77 \\
\hline $\mathrm{SB} 4<2 \mu \mathrm{m}$ & -90 \\
\hline SB4 $2-6 \mu \mathrm{m}$ & -85 \\
\hline $\mathrm{BF} 1<0.1 \mu \mathrm{m}$ & -106 \\
\hline $\mathrm{BF} 1<0.4 \mu \mathrm{m}$ & -103 \\
\hline $\mathrm{BF} 1<2 \mu \mathrm{m}$ & -100 \\
\hline BF1 2-6 $\mu \mathrm{m}$ & -97 \\
\hline BF1 6-10 $\mu \mathrm{m}$ & -96 \\
\hline BF1 WR & -85 \\
\hline $\mathrm{BF} 2<0.1 \mu \mathrm{m}$ & -108 \\
\hline $\mathrm{BF} 2<0.4 \mu \mathrm{m}$ & -100 \\
\hline $\mathrm{BF} 2<2 \mu \mathrm{m}$ & -97 \\
\hline BF2 2-6 $\mu \mathrm{m}$ & -93 \\
\hline BF2 6-10 $\mu \mathrm{m}$ & -91 \\
\hline BF2 WR & -90 \\
\hline
\end{tabular}

TEM images of the finest $(<0.1 \mu \mathrm{m})$ clay fractions show that the dated K-bearing illite/muscovite grains have a pseudohexagonal platelet form (Fig. 5b) typical of the $2 \mathrm{M}_{1}$ polytype (Inoue et al. 1988; Schleicher et al. 2006), confirming the quantitative XRD results that $2 \mathrm{M}_{1}$ is the only polytype present. The idiomorphic morphology of some of these very fine grains (Fig. 5b), together with their K-deficient chemistry relative to muscovite (Fig. 4), is direct evidence for authigenic growth of $2 \mathrm{M}_{1}$ illite, at least in the southerly Matrei samples (BF1, BF2), which generally give the younger $\mathrm{K}-\mathrm{Ar}$ ages. The lack of any mixed layer illite/smectite or lower temperature $1 \mathrm{M} / 1 \mathrm{M}_{\mathrm{d}}$ polytype illite is rather atypical of clay fault gouges: most other reported examples show a variable mixture of clay minerals and polymorphs, reflecting the range of initial and retrograde conditions during faulting and exhumation (Kralik et al. 1987; Zwingmann and Mancktelow 2004; Zwingmann et al. 2010a, b; Surace et al. 2011; Pleuger et al. 2012; Bense et al. 2014). Considering only the dateable K-bearing illite in such mixtures, many authors have argued that the $1 \mathrm{M} / 1 \mathrm{M}_{\mathrm{d}}$ polytype represents the authigenic component grown during faulting, whereas the $2 \mathrm{M}_{1}$ part represents relict protolith or "detrital" grains. Based on this principle, extrapolation of a plot of vol\% $2 \mathrm{M}_{1} /\left(2 \mathrm{M}_{1}+1 \mathrm{M}+1 \mathrm{M}_{\mathrm{d}}\right)$ versus apparent $\mathrm{K}-\mathrm{Ar}$ age, $\mathrm{Ar}-\mathrm{Ar}$ age, or $\mathrm{e}^{\lambda t}-1$ (where $\lambda$ is the decay constant and $t$ is time) can provide both the protolith (100\%) and authigenic $(0 \%)$ ages (Pevear 1999; Van der Pluijm et al. 2001, 2006; Ylagan et al. 2002; Haines and van der Pluijm
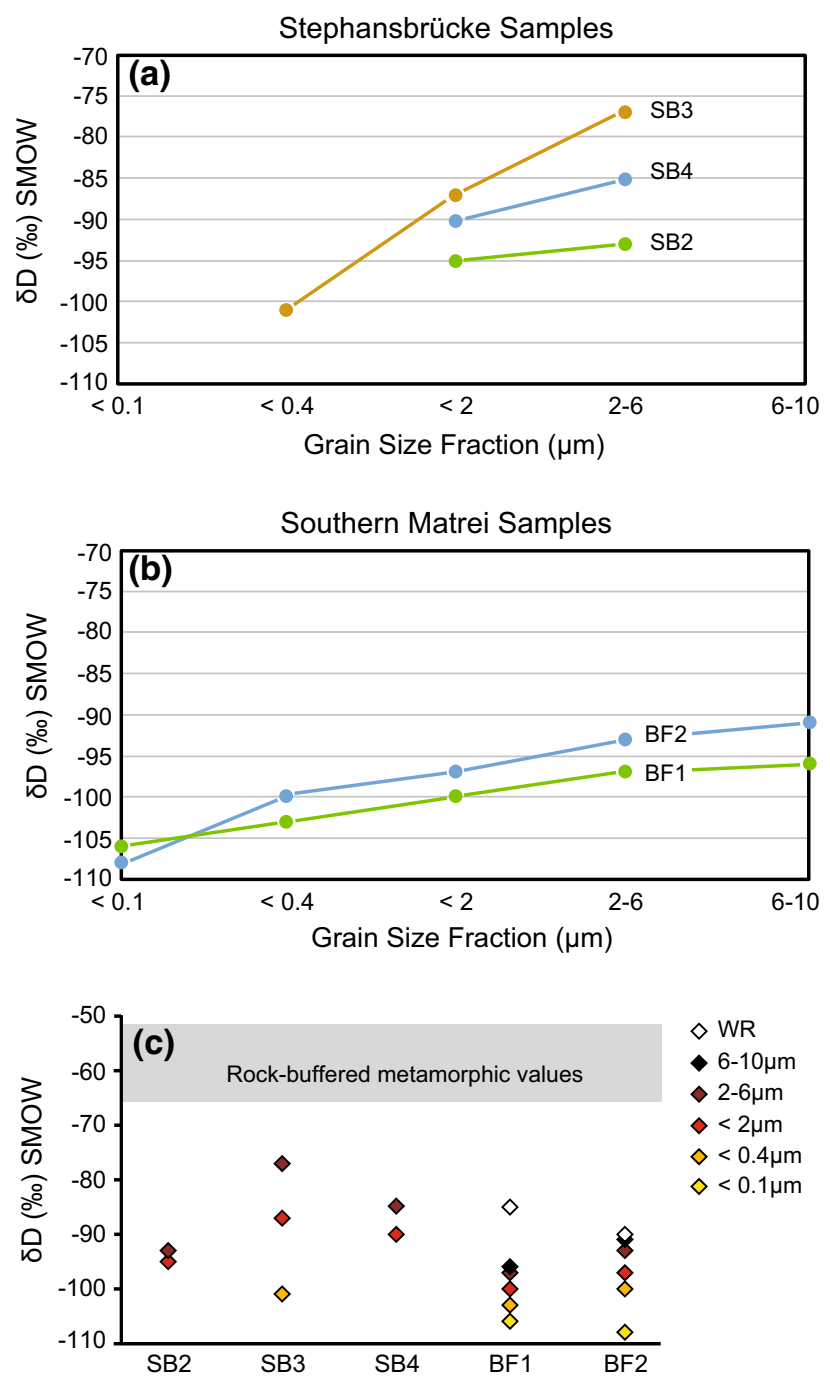

Fig. 8 Plot of $\delta D$ values versus the grain size of the analysed fractions, for samples from $\mathbf{a}$ the Stephansbrücke area and $\mathbf{b}$ the more southerly Matrei area. Note that the youngest Stephansbrücke sample (SB4 $<0.1 \mu \mathrm{m}$ ) was not analysed for $\delta \mathrm{D}$. c Comparison of the $\delta \mathrm{D}$ values calculated for each clay gouge samples versus grain size. The grey area represents the high $\delta \mathrm{D}$ values $(-60 \%)$ of the muscovites from the footwall and hanging wall of the Brenner Fault Zone

2010; Solum et al. 2010; Duvall et al. 2011; Hnat and van der Pluijm 2014).

However, it has also been clearly demonstrated in a range of natural examples that authigenic $2 \mathrm{M}_{1}$ illite can form in fault gouges derived from metamorphic or magmatic protoliths that were initially devoid of such illite (Zwingmann and Mancktelow 2004; Zwingmann et al. 2010a; Viola et al. 2013; Bense et al. 2014; Song et al. 2014; Torgersen and Viola 2014; Torgersen et al. 2014a). In particular, Viola et al. (2013) have recently described a clay fault gouge in the Palaeoproterozoic basement of Finland that contained almost exclusively $2 \mathrm{M}_{1}$ illite/muscovite as authigenic clay, developed from a protolith gneiss 

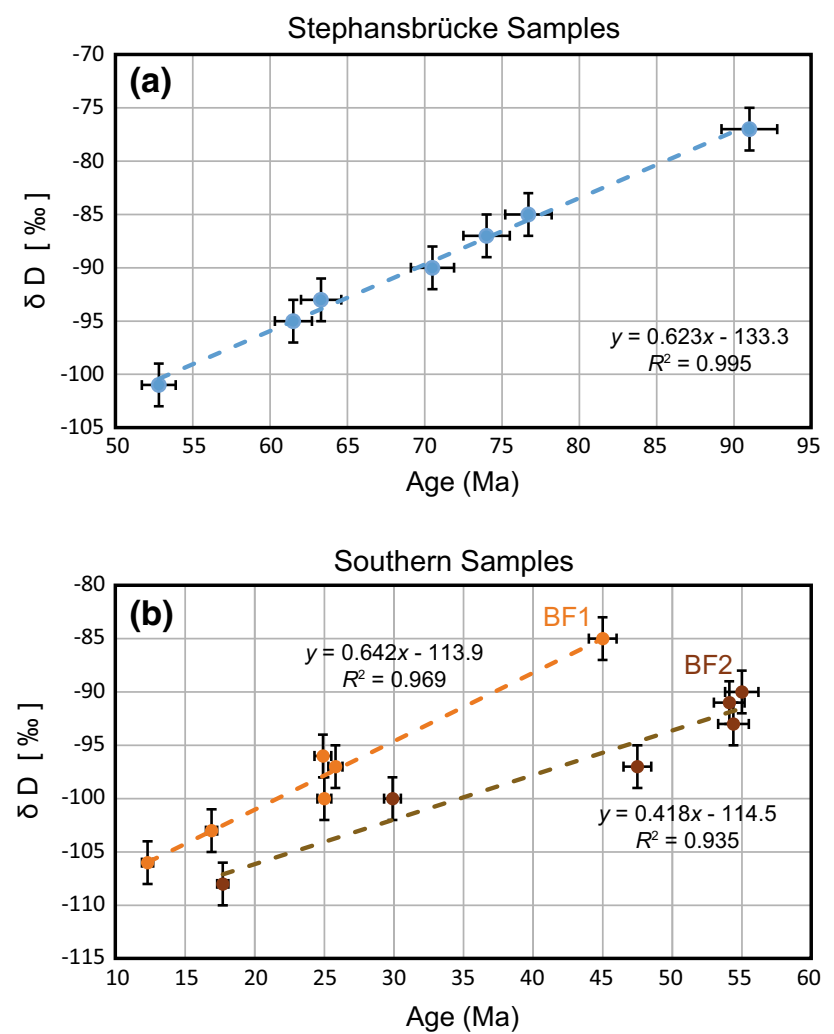

Fig. 9 Plot of $\delta \mathrm{D}$ values versus $\mathrm{K}-\mathrm{Ar}$ age for the analyzed size fractions, for samples from $\mathbf{a}$ the Stephansbrücke area and $\mathbf{b}$ the more southerly Matrei area. Note the very good linear correlation, especially for the Stephansbrücke area. The error in $\delta \mathrm{D}$ is taken as $\pm 2 \%$, the analytical error in the $\mathrm{K}-\mathrm{Ar}$ ages is from Table 2. Data table for the plot is available in Online Resource 4

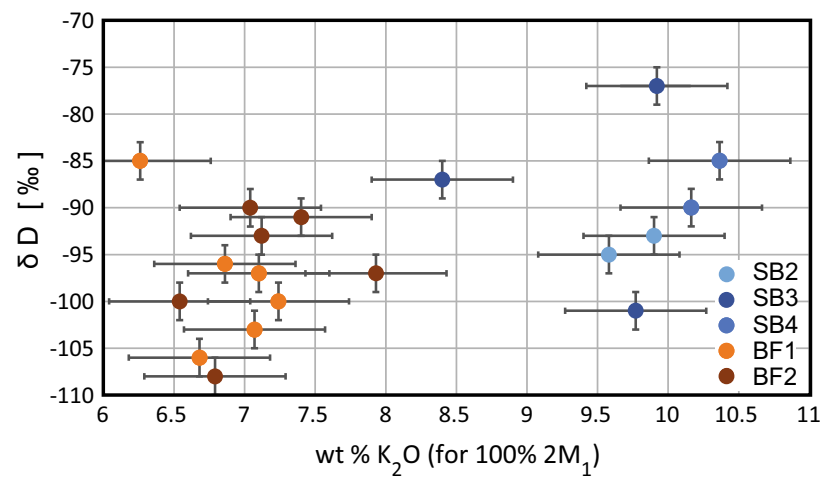

Fig. 10 Plot of $\delta D$ values against recalculated wt $\% \mathrm{~K}_{2} \mathrm{O}$ extrapolated to $100 \% 2 \mathrm{M}_{1}$ component (Fig. 7). The error in $\delta \mathrm{D}$ is taken as $\pm 2 \%$; the error in recalculated wt $\% \mathrm{~K}_{2} \mathrm{O}$ cannot be estimated accurately, but is conservatively plotted as $\pm 0.5 \%$. Data table for the plot is available in Online Resource 5

that contained no illite and $<4 \%$ protolith muscovite. In all these reported cases, authigenic $2 \mathrm{M}_{1}$ illite must have grown under higher temperature hydrothermal conditions, presumably during the initial stages of fault zone development
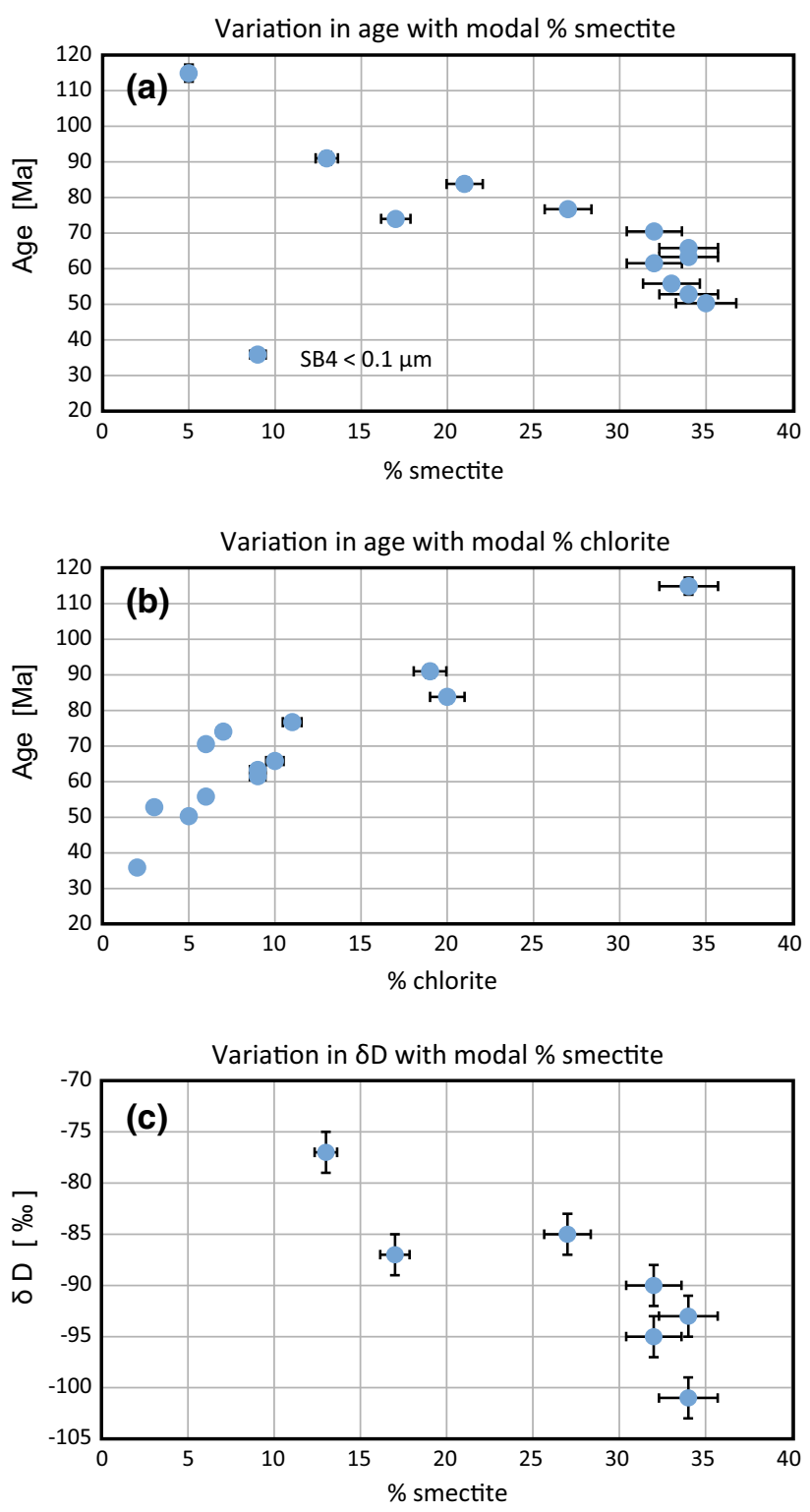

Fig. 11 Relationship between measured $\mathrm{K}-\mathrm{Ar}$ age from the different size fractions for the northerly Stephansbrïcke (SB) samples (Table 2) and the modal \% of smectite and chlorite (Table 1), determined by quantitative $\mathrm{X}$-ray diffraction. a $\mathrm{K}$-Ar age versus \% smectite; note the one clear outlier for SB4 $<0.1 \mu \mathrm{m}$; b $\mathrm{K}-\mathrm{Ar}$ age versus \% chlorite; c $\delta \mathrm{D}$ versus $\%$ smectite. Data table for the plot is available in Online Resource 6

at depths close to the ductile-brittle transition. For quartzrich rocks, this occurs around $280-300{ }^{\circ} \mathrm{C}$ (Sibson et al. 1979; White and White 1983; Mancktelow 1985; Stipp et al. 2002). Velde (1965) established experimentally that $2 \mathrm{M}_{1}$ muscovite is stable down to $125^{\circ} \mathrm{C}$. As shown by Yoder and Eugster (1955) and Yoder (1957), the retrograde polymorphic transformation of $2 \mathrm{M}_{1}$ to $1 \mathrm{M}$ is also very sluggish (and not attainable experimentally). In natural examples of regional metamorphism in pelitic rocks, the 
gradational prograde transformation of $1 \mathrm{M} / 1 \mathrm{M}_{\mathrm{d}}$ illite to $2 \mathrm{M}_{1}$ illite/muscovite begins in the lowermost anchizone and is effectively completed by the transition to the epizone (e.g. Hunziker et al. 1986; cf. their Fig. 5), corresponding to a temperature range of ca. $200-300{ }^{\circ} \mathrm{C}$ (Merriman and Frey 1999). Initiation of brittle faulting and gouge development in the upper continental crust can therefore occur within the stability field of $2 \mathrm{M}_{1}$ illite, which may be authigenic and not invariably represent an inherited "detrital" or protolith component.

The $\delta \mathrm{D}$ values of phyllosilicates (muscovite, biotite and chlorite) collected within the footwall and hanging wall of the Brenner Fault Zone are typical of a rock-buffered metamorphic system and do not indicate any interaction with meteoric fluids away from the fault zone (Table 3). However, compared to $\delta \mathrm{D}$ values of around $-60 \%$ for $2 \mathrm{M}_{1}$ white micas from the footwall and hanging wall, $\delta \mathrm{D}$ values from the fault gouges are much more negative (Fig. 8c). They are especially negative (down to $<-108 \%$ ) within samples BF1 and BF2 from the southern Matrei region, which are only composed of $2 \mathrm{M}_{1}$ illite/muscovite. Low $\delta \mathrm{D}$ in white micas $(\delta \mathrm{D}<-80 \%$ ) can only be explained by hydrogen isotope exchange with a meteoric fluid with low $\delta \mathrm{D}$ values (e.g. Mulch et al. 2004; Gébelin et al. 2015) and an important influence of meteoric water in samples BF1 and BF2 is thus clearly established. For both gouge samples, a well-defined linear relationship between $\delta \mathrm{D}$ values and $\mathrm{K}-\mathrm{Ar}$ (apparent) ages is observed (Fig. 9b). This correlation between (apparent) age and isotopic composition indirectly reflects the influence of grain size on both isotopic composition and $\mathrm{K}-\mathrm{Ar}$ age, with the finest fractions yielding the youngest $\mathrm{K}-\mathrm{Ar}$ ages (Fig. 6) and the lowest $\delta D$ values, which in turn implies the strongest (meteoric) fluid-rock interaction (Fig. 8). A similar relationship between $\mathrm{K}-\mathrm{Ar}$ age of illite, grain size and $\delta^{18} \mathrm{O}$ was reported by Cathelineau et al. (2004) in fractured and altered plutonites from the French Massif Central, although in their case the value of $\delta^{18} \mathrm{O}$ increased with decreasing grain size and $\mathrm{K}-\mathrm{Ar}$ age.

The Stephansbrücke samples from further north are dominantly composed of the same $2 \mathrm{M}_{1}$ polytype. However, they also contain smectite that must have formed nearsurface at low temperatures $\left(<80^{\circ} \mathrm{C}\right)$ and is therefore likely to record strong isotopic exchange with surfacederived fluids, which should lower the measured $\delta \mathrm{D}$ values. Despite this, the $\delta \mathrm{D}$ values for comparable size fractions are generally higher in the Stephansbrücke samples than in the southern Matrei samples (Fig. 8). As seen from Fig. 9a, a clear linear relationship between $\delta \mathrm{D}$ values and $\mathrm{K}-\mathrm{Ar}$ (apparent) ages of the $2 \mathrm{M}_{1}$ illite/muscovite component is still observed and in fact the correlation is even stronger than that for samples BF1 and BF2 (Fig. 9b). It follows that the presence of smectite seems to have had only a minor impact on the overall $\delta \mathrm{D}$ values. As discussed already in Sect. 5.4 above, all samples trend towards a value of around $-108 \%$ for the finest grained fractions returning the youngest apparent $\mathrm{K}-\mathrm{Ar}$ ages (Fig. 9).

In summary, the hydrogen isotope results in this study clearly document that meteoric water has infiltrated the Silltal fault gouge during brittle faulting, but that this infiltration was localised at the contact between hanging wall and footwall and did not reach deeper structural levels of the detachment system. The brittle fault gouge that marks the contact between hanging wall and footwall therefore appears to be the main pathway for fluid infiltration. This fluid infiltration pattern is in contrast to that from the other directly comparable major Alpine low-angle detachment in the Central Alps, the Simplon Fault Zone (SFZ), where surface-derived fluid infiltrated the detachment via a wide zone of brittle deformation and reached the depth of the ductile-to-brittle transition (Campani et al. 2012).

In interpreting the observations from the Silltal Fault on the clay mineralogy, chemistry, morphology, H-isotopes, and apparent $\mathrm{K}-\mathrm{Ar}$ ages, as well as their dependence on grain size, two end-member models need to be critically assessed. (1) The $2 \mathrm{M}_{1}$ polytype found in all samples is metamorphic muscovite derived from the Innsbruck Quartz Phyllite and the only authigenic clay is the low-grade smectite developed in samples from the Stephansbrücke locality. The $2 \mathrm{M}_{1}$ grains in all size fractions are original protolith muscovite whose grain size has been mechanically reduced by cataclasis and grinding in the fault zone. The dependence of apparent age on grain size reflects grain-size dependent loss of radiogenic argon during deformation and comminution in a hydrothermal environment (Dodson 1973; Villa 1998). (2) The $2 \mathrm{M}_{1}$ polytype in the finest fractions is higher temperature illite that has neocrystallized due to fluid-rock interaction in the cataclastic fault zone. The dependence of apparent age on grain size reflects either a variable mixture with coarser grained protolith $2 \mathrm{M}_{1}$ muscovite or with earlier formed, coarser authigenic illite (e.g. Clauer et al. 2012), or both.

At least for the northern samples from near Stephansbrücke, the implied composition of most clay-sized fractions is identical to the composition of muscovite from the adjacent footwall Innsbruck Quartz Phyllite and Patscherkofel Crystalline Complex (Figs. 4, 7). The K-Ar ages also overlap with those from the Patscherkofel Crystalline Complex (Fig. 7). However, the two Stephansbrücke samples richest in $2 \mathrm{M}_{1}$ component (SB3 $<2 \mu \mathrm{m}$ and SB4 $<0.1 \mu \mathrm{m}$ ) are deficient in $\mathrm{K}$ and lie within the illite field. These two samples contain respectively 75 and $88 \% 2 \mathrm{M}_{1}$ illite/muscovite, whereas the usual Innsbruck Quartz Phyllite typically contains 25-30\% muscovite (see photomicrograph in Fig. 4b of Madritsch and Millen 2007). If the $2 \mathrm{M}_{1}$ component in the clay gouge 
samples is entirely metamorphic muscovite, it must have been concentrated by a factor two or more relative to the protolith Innsbruck Quartz Phyllite, presumably by dissolution of original quartz and plagioclase. Quartz dissolution is reported from fault gouge zones, but only to a more limited extent (e.g. Chester and Logan 1986). It should also be noted that although the $2 \mathrm{M}_{1}$ component generally increases with decreasing grain size, the opposite is the case for chlorite (Table 1), which is the other phyllosilicate originally present in the Innsbruck Quartz Phyllite. Bense et al. (2014) argued that diminution of coarse protolith muscovite to micron or sub-micron grain sizes is unlikely, because of the very strong mechanical resistance of this mineral. However, direct experiments on synthetic muscovite fault gouges contradict this supposition, with lower temperature runs $\left(300{ }^{\circ} \mathrm{C}\right)$ under hydrothermal conditions developing fine grained shear bands with matrix grain sizes $<2 \mu \mathrm{m}$ (Van Diggelen et al. 2010).

As noted above, the two samples richest in $2 \mathrm{M}_{1}$ component from the Stephansbrücke, as well as all the samples from the southern Matrei area, are deficient in $\mathrm{K}$ and fall within the compositional range of illite (Fig. 4). However, muscovite can also be leached and lose $\mathrm{K}$ by interaction with low-K-activity, slightly acid water (Scott and Reed 1966; Scott and Smith 1966; Feigenbaum et al. 1981; Song and Huang 1988; Derkowski et al. 2014), which could be possible for meteoric water fluxing a fault zone developed in schist and gneiss. Such leaching would change the chemical composition of cataclastically comminuted muscovite grains towards more K-deficient illite without neocrystallization. In particular, Feigenbaum et al. (1981) found that the relative rate of $\mathrm{K}$ release from muscovite (and biotite and phlogopite) is much higher than the rate of $\mathrm{K}$ release from illite (Feigenbaum and Shainberg 1975) in $0.001 \mathrm{~N} \mathrm{HCl}$ solutions, despite the fact that in their experiments the illite particles were clay size $(<2 \mu \mathrm{m})$ and the mica particles were 5-20 $\mu \mathrm{m}$. Scott and Smith (1966) note, however, that very low values of dissolved $\mathrm{K}$ are required for $\mathrm{K}$ release by muscovite (and illite), although more than $90 \%$ of the $\mathrm{K}$ in muscovite (and biotite and phlogopite) is in fact exchangeable with $\mathrm{Na}$ (and other cations, e.g. Graf von Reichenbach and Rich 1969). In summary, numerous studies considering weathering (Scott and Reed 1966; Scott and Smith 1966; Graf von Reichenbach and Rich 1969) and hydrothermal alteration (Meyer and Hemley 1957; Hemley 1959) have demonstrated that $\mathrm{K}$ leaching from muscovite is possible in fluids of appropriate composition. However, preferentially leaching $\mathrm{K}$ and largely retaining the radiogenic argon, as considered by Derkowski et al. (2014), would lead to older apparent ages with increasing fluid-rock interaction in the finest grains, which is the opposite of what is observed. The experiments of Clauer et al. (1993) and Clauer and Mongodin (2012) show that acidic leaching does not induce a preferential release of radiogenic isotopes or a significant effect on the concentration of $\mathrm{Al}$ and $\mathrm{K}$ (and $\mathrm{Mg}$ ) in illite/muscovite. They therefore argue that such leaching should not substantially modify $\mathrm{K}-\mathrm{Ar}$ and ${ }^{40} \mathrm{Ar} /{ }^{39} \mathrm{Ar}$ ages.

Argon loss due to diffusion is a function of grain size and temperature (Dodson 1973) and can be strongly affected by intracrystalline deformation and fluid interaction (Villa 1998; Mulch et al. 2002). For fine-grained white mica $<2 \mu \mathrm{m}$, Hunziker et al. (1986) reported a closure temperature interval (corresponding to the end of significant diffusion of Ar) of $260 \pm 30^{\circ} \mathrm{C}$, whereas Wemmer and Ahrendt (1997) considered it to lie somewhere between 275 and $350{ }^{\circ} \mathrm{C}$. The stability field of $2 \mathrm{M}_{1}$ illite and the temperature of its transition to muscovite, as well as the brittle-ductile transition in quartz-rich rocks, overlaps with this proposed closure temperature range. Zircon fission track ages from both the footwall and the hanging wall of the Silltal Fault north of Matrei are rather similar and indicate that this region had already cooled below $\sim 300{ }^{\circ} \mathrm{C}$ in the early Palaeocene (Fügenschuh et al. 1997), which is markedly older than the youngest $\mathrm{K}-\mathrm{Ar}$ ages obtained in the finest fractions from both the Stephansbrücke and (especially) the Matrei area. Nevertheless, it cannot be excluded that the observed decrease in apparent $\mathrm{K}-\mathrm{Ar}$ age with grain size in the analysed fault gouges may reflect partial loss of Ar from protolith muscovite grains during deformation, comminution and interaction with water in the fault zone. Ar loss would be promoted by damage to the crystal lattice, caused by grain size reduction, as well as by the decreased diffusion distance in such defect-rich grains. Ar loss would also be aided by interaction with water in the fault zone, due to infiltration of water along cracks, cleavage planes and dislocation cores. Geothermal waters of higher temperature in the fault zone could also have promoted Ar loss.

However, the temperature range above $260-280{ }^{\circ} \mathrm{C}$ for which Ar loss in fine grained muscovite may start to be significant is also well within the temperature range of 125-350 ${ }^{\circ} \mathrm{C}$ for which $2 \mathrm{M}_{1}$ illite is known to form in epithermal conditions (e.g. Velde 1965; Schleicher et al. 2006). The observed idiomorphic grain boundaries in the finest analysed fractions with typical $2 \mathrm{M}_{1}$ pseudohexagonal platelet forms (Fig. 5b) is direct evidence for authigenic $2 \mathrm{M}_{1}$ illite growth, as is the $\mathrm{K}$-deficient illite chemical composition of all the southern Matrei samples (which return the youngest ages). The trend of decreasing Tertiary ages in apatite fission track ages from north to south in the hanging wall of the Silltal Fault (Fig. 2) (Fügenschuh et al. 2000) indicates increasing depth of post-Tertiary exhumation to the south and therefore that temperatures during fault gouge formation in the southern samples from the Silltal Fault were higher. This would promote new higher temperature $2 \mathrm{M}_{1}$ illite growth, as seen directly in the TEM 
images, as well as potentially accelerate argon loss from finer grained protolith muscovite grains, both of which would result in younger apparent ages in the finest fractions from the southern samples.

In summary, there is direct evidence for new $2 \mathrm{M}_{1}$ illite growth in the finest fraction $(<0.1 \mu \mathrm{m})$ of the higher temperature southern samples, and it is this fraction that has the highest vol\% of the $2 \mathrm{M}_{1}$ polytype and the youngest age $(12.3 \pm 0.4 \mathrm{Ma})$. If there was no subsequent argon loss, the age of this finest fraction $(<0.1 \mu \mathrm{m})$ in general corresponds to growth of the finest, and usually most recently nucleated, illite in the fault gouge (Zwingmann and Mancktelow 2004; Zwingmann et al. 2010a; Torgersen et al. 2014a). However, faults always accumulate displacement over a finite time span and, in some cases, may be intermittently active over long times (Mulch et al. 2005; Viola et al. 2013; Torgersen and Viola 2014; Torgersen et al. 2014a, b). Particularly when dates derive from the higher temperature $2 \mathrm{M}_{1}$ illite polytype, developed closer to the brittle-ductile transition, it is unlikely that $\mathrm{K}-\mathrm{Ar}$ ages correspond only to the very last deformation increments on the fault (Zwingmann et al. 2010a), which may have continued to be active under retrograde conditions during exhumation to the surface. For the example of the Silltal Fault presented here, apparent K-Ar ages from the finest to the coarsest size fractions (and "whole-rock gouge" samples) range from Middle Miocene ( $\sim 12 \mathrm{Ma}$ ) to Cretaceous $(\sim 115 \mathrm{Ma})$. The question then arises whether this range reflects extended activity on the fault or simply a mixture of authigenic young clay, reflecting the time of actual movement, and older protolith grains, which may be partly reset by Ar-loss during grain deformation and fluid rock interaction in the cataclastic fault zone. As discussed in some detail above, this cannot be unequivocally established-the youngest ages are taken to reflect active fault movement around $12 \mathrm{Ma}$, but initiation of faulting could certainly have been significantly earlier.

The K-Ar fault gouge ages from the current study are broadly consistent with regional constraints on the possible time of activity of the Silltal Fault. ${ }^{40} \mathrm{Ar} /{ }^{39} \mathrm{Ar}$ ages on white mica separates from both the hanging wall and the footwall of the Silltal Fault give mixed Permian to Cretaceous ages, in the range of 270-130 Ma (Fig. 2) (Thöni 1980, 1999; Thöni and Hoinkes 1987; Rockenschaub et al. 2003), which are generally older than the oldest ages obtained from the Silltal Fault in this study. The only exception is sample 77/97 from the mylonitic base of the Patscherkofel Crystalline Complex klippe (Fig. 2), which shows a series of steps in the ${ }^{40} \mathrm{Ar} /{ }^{39} \mathrm{Ar}$ spectrum between 120 and $50 \mathrm{Ma}$ (Rockenschaub et al. 2003). As noted above, extrapolation of this contact to the west downslope suggests it should intersect the Silltal Fault in the vicinity of the Stephansbrücke samples, but outcrop conditions do not allow direct confirmation of this in the field. However, it certainly is the case that both the composition of the $2 \mathrm{M}_{1}$ illite/muscovite and the $\mathrm{K}-\mathrm{Ar}$ age of the "whole-rock gouge" and coarser separates from the Stephansbrücke clay gouges overlap with the composition and ${ }^{40} \mathrm{Ar} /{ }^{39} \mathrm{Ar}$ ages on white mica from the retrograde mylonitic shear zone at the base of the Patscherkofel Crystalline Complex (e.g. Fig. 7). As noted in the Geological overview (Sect. 2), Rockenschaub et al. (2003) interpret these younger ages down to $50 \mathrm{Ma}$ to reflect retrograde metamorphism and mylonitization related to top-to-west final emplacement of the Patscherkofel Crystalline Complex. This top-down-to-the-west kinematics is identical to that related to the Silltal Fault at Stephansbrücke. It follows that the oldest measured K-Ar ages in the "whole-rock gouge" and coarser grained separates from the Stephansbrücke area, spanning the range from 65 to $155 \mathrm{Ma}$, most likely represent inherited protolith muscovite grains from the Patscherkofel Crystalline Complex basal shear zone. The decreasing age spectrum with grain size could represent: (1) partial Ar loss from cataclastically comminuted protolith muscovite grains interacting with the documented influx of hydrothermal meteoric water into the fault zone-these partially reset apparent ages would have no real geological significance; (2) authigenic growth of higher temperature $2 \mathrm{M}_{1}$ illite/muscovite reflecting ongoing but possibly intermittent activity of the Patscherkofel Crystalline Complex basal shear zone, and its transition to brittle faulting and fault gouge formation on the Silltal Fault; (3) a mixture between comminuted protolith muscovite grains and authigenic new illite, whose minimum age is given by the youngest ages from the finest fractions-in this case only the youngest ages would have a geological significance.

The probable time of brittle faulting on the Brenner Fault Zone south of Matrei (Fig. 1) can be derived from the cooling history of the western Tauern window, which represents the footwall of the Brenner Fault Zone in this area. Here, the footwall cools through $300{ }^{\circ} \mathrm{C}$ at around 13-14 Ma and $200{ }^{\circ} \mathrm{C}$ at around $12 \mathrm{Ma}$ (Fig. $2 \mathrm{~b}$ of Fügenschuh et al. 1997), so that protracted brittle movements on the Brenner Fault Zone are expected to be around $13 \mathrm{Ma}$ or younger. However, zircon fission track ages from both the footwall and the hanging wall of the Silltal Fault north of Matrei are rather similar and indicate that this area had already cooled below $\sim 300{ }^{\circ} \mathrm{C}$ in the early Palaeocene (Fügenschuh et al. 1997). The transition to brittle behaviour in the region of the current Silltal Fault may therefore be older, both in the hanging wall and in the footwall, than further to the south. Unlike the Brenner Fault Zone south of Matrei, which forms the western boundary of the Tauern window, the Silltal Fault north of Matrei does not juxtapose markedly different crustal levels, any vertical component must have been modest, and brittle faulting 
may have initiated at higher crustal levels and at lower temperatures (at least in the footwall) compared to the Brenner Fault Zone continuation further south. The finest grained fault gouge samples from the Silltal Fault samples near Matrei give ages around 12-18 Ma, consistent with the independently estimated time of movement on the Brenner Fault Zone $<20$ Ma (Fügenschuh et al. 1997), with the youngest age corresponding to the interpreted transition to brittle faulting in the Tauern window footwall of Brenner Fault Zone at around 12-13 Ma.

\section{Conclusions}

The results presented here from the Silltal Fault in the Eastern Alps form an internally consistent data set, but one that is challenging both with regard to the common assumptions involved in fault gouge dating and in applying the results to interpreting the tectonic history of this fault. Many authors have argued that in clay fault gouges the $2 \mathrm{M}_{1}$ polytype is entirely derived from "detrital" higher temperature illite or protolith metamorphic muscovite and should preserve a pre-faulting age for faults developed under relatively cool $\left(<\sim 250-280{ }^{\circ} \mathrm{C}\right)$, near-surface brittle conditions. In this interpretation, the authigenic clay component that is newly grown during faulting should consist of lower temperature $1 \mathrm{M} / 1 \mathrm{M}_{\mathrm{d}}$ polytypes and mixed layer illite/smectite. Only the age information from these polytypes would therefore reflect the time of fault activity. A plot of percentage of $2 \mathrm{M}_{1}$ polytype against apparent $\mathrm{K}-$ Ar or ${ }^{40} \mathrm{Ar} /{ }^{39} \mathrm{Ar}$ age for several size fractions can thus be extrapolated to pure authigenic and pure "detrital" illite end member ages, if these are the only two K-bearing components within the sample.

In samples from the Silltal Fault there is no lower temperature $1 \mathrm{M} / 1 \mathrm{M}_{\mathrm{d}}$ polytype, only $2 \mathrm{M}_{1}$, but there is a strong correlation of decreasing age with decreasing grain size of the clay fraction. There is also a very well-defined linear correlation between $\delta \mathrm{D}$ values and the $\mathrm{K}-\mathrm{Ar}$ ages of the $2 \mathrm{M}_{1}$ illite/muscovite component, implying a direct relationship between decreased age and increased (meteoric) fluid-rock interaction. The low $\delta \mathrm{D}$ values indicative of strong interaction with meteoric water are entirely restricted to the narrow fault gouge and are not observed in the adjacent footwall and hanging wall, where values are typical of fluids buffered against metamorphic rocks. We conclude, particularly based on the amount of $2 \mathrm{M}_{1}$ polytype present and from direct TEM observation of the grain morphology, that there has been new $2 \mathrm{M}_{1}$ illite growth in the clay gouge of the Silltal Fault, especially in the southern samples from near Matrei that return the youngest ages in the finest fractions. From the regional metamorphic gradient, the Silltal Fault near Matrei probably initiated under slightly higher temperatures, conducive to authigenic $2 \mathrm{M}_{1}$ illite growth. The youngest ages around $12 \mathrm{Ma}$ are geologically meaningful and reflect the time of Neogene brittle displacement on the Silltal-Brenner Fault Zone system. The increasing age with increasing grain size in other sample size fractions may reflect either a mixture with older, coarser authigenic illite/muscovite grown during a more extended period of fault activity or a mixture with protolith ("detrital") white mica. This protolith mica component may have suffered partial, grain-size-dependent, radiogenic Ar loss (and possibly also K loss) during cataclastic grain comminution and deformation, with this leaching enhanced by hydrothermal interaction with channelized meteoric water in the fault zone. In this case, the older apparent $\mathrm{K}$-Ar ages are not geologically meaningful but only record partial reset of protolith muscovite incorporated from adjacent muscovite-bearing phyllites during faulting.

Acknowledgments A. Todd and M. Raven, CSIRO, are thanked for technical assistance. The study was part of the collaborative TopoAlps project within the framework of the European Science Foundation (ESF) Eurocores Programme TOPO-EUROPE, and was funded by the Swiss National Science Foundation (SNF projects 200021-134469 and 200021-120502). AM also acknowledges support through DFG Mu2845/2-1 in the framework of the ESF TOPOEUROPE Program and the LOEWE program of Hesse's Ministry of Higher Education, Research, and the Arts. We also thank J. Fiebig (Goethe University Frankfurt) at the Joint Goethe University-BiK-F Stable Isotope Facility. HZ acknowledges the use of equipment of the Curtin University Electron Microscope Facility, which is partially funded by the University, State and Commonwealth Governments. Constructive reviews by E. Torgersen and an anonymous reviewer helped to improve the manuscript and are gratefully acknowledged.

\section{References}

Bailey, S. W. (1984). Micas (p. 584). Washington, D.C.: Mineralogical Society of America.

Bauer, A., Velde, B., \& Gaupp, R. (2000). Experimental constraints on illite crystal morphology. Clay Minerals, 35, 587-597.

Behrmann, J. H. (1988). Crustal-scale extension in a convergent orogen: the Sterzing-Steinach mylonite zone in the Eastern Alps. Geodinamica Acta, 2, 63-73.

Bense, F. A., Wemmer, K., Lobens, S., \& Siegesmund, S. (2014). Fault gouge analyses: K-Ar illite dating, clay mineralogy and tectonic significance-a study from the Sierras Pampeanas, Argentina. International Journal of Earth Sciences, 103, 189-218.

Berthé, D., Choukroune, P., \& Jegouzo, P. (1979). Orthogneiss, mylonite and non coaxial deformation of granites: the example of the South Armorican Shear Zone. Journal of Structural Geology, 1, 31-42.

Blaas, J. (1885). Ueber die Glacialformation im Innthale. Zeitschrift des Ferdinandeums für Tirol und Vorarlberg, 3(29), 1-120.

Bonhomme, M. G., Thuizat, R., Pinault, Y., Clauer, N., Wendling, R., \& Winkler, R. (1975). Méthode de datation potassium-argon. In Appareillage et Technique (p. 53). Strasbourg. 
Campani, M., Herman, F., \& Mancktelow, N. (2010a). Two- and three-dimensional thermal modeling of a low-angle detachment: exhumation history of the Simplon Fault Zone, central Alps. Journal of Geophysical Research-Solid Earth, 115, B10420. doi:10.1029/2009JB007036.

Campani, M., Mancktelow, N., Seward, D., Rolland, Y., Muller, W., \& Guerra, I. (2010b). Geochronological evidence for continuous exhumation through the ductile-brittle transition along a crustalscale low-angle normal fault: Simplon Fault Zone, central Alps. Tectonics, 29, TC3002. doi:10.1029/2009TC002582.

Campani, M., Mulch, A., Kempf, O., Schlunegger, F., \& Mancktelow, N. (2012). Miocene paleotopography of the Central Alps. Earth and Planetary Science Letters, 337, 174-185.

Cathelineau, M., Fourcade, S., Clauer, N., Buschaert, S., Rousset, D., Boiron, M.-C., et al. (2004). Dating multistage paleofluid percolations: a K-Ar and ${ }^{18} \mathrm{O} /{ }^{16} \mathrm{O}$ study of fracture illites from altered Hercynian plutonites at the basement/cover interface (Poitou High, France). Geochimica et Cosmochimica Acta, 68, 2529-2542.

Chester, F. M., \& Logan, J. M. (1986). Implications for mechanical properties of brittle faults from observations of the Punchbowl fault zone, California. Pure and Applied Geophysics, 124, 79-106.

Clauer, N. (2013). The K-Ar and ${ }^{40} \mathrm{Ar} /{ }^{39} \mathrm{Ar}$ methods revisited for dating fine-grained K-bearing clay minerals. Chemical Geology, $354,163-185$.

Clauer, N., \& Chaudhuri, S. (1995). Clays in crustal environments: isotope dating and tracing (p. 359). Berlin: Springer.

Clauer, N., Chaudhuri, S., Kralik, M., \& Bonnot-Courtois, C. (1993). Effects of experimental leaching on $\mathrm{Rb}-\mathrm{Sr}$ and $\mathrm{K}-\mathrm{Ar}$ isotopic systems and REE contents of diagenetic illite. Chemical Geology, 103, 1-16.

Clauer, N., Liewig, N., \& Zwingmann, H. (2012). Time-constrained illitization in gas-bearing Rotliegende (Permian) sandstones from northern Germany by illite potassium-argon dating. American Association of Petroleum Geologists (AAPG) Bulletin, 96, 519-543.

Clauer, N., \& Mongodin, Y. (2012). Chemical and K-Ar systematics of a mylonitic mica after natural and experimental interactions with varied fluids. Chemical Geology, 294-295, 18-25.

Clauer, N., Williams, L. B., \& Fallick, A. E. (2014). Genesis of nanometric illite crystals elucidated by light-element (hydrogen, lithium, boron and oxygen) isotope tracing, and $\mathrm{K}-\mathrm{Ar}$ and $\mathrm{Rb}-\mathrm{Sr}$ dating. Chemical Geology, 383, 26-50.

Czurda, K. A., \& Bertha, S. (1984). Verbreitung und rohstoffmäßige Eignung von Tonen und Tongesteinen in Nordtirol. Archiv für Lagerstättenforschung der Geologischen Bundesanstalt, 5, 15-28.

Dalla Torre, M., \& Frey, M. (1997). The evolution from disordered Ad to ordered $2 \mathrm{M}_{1}$ white $\mathrm{K}$-mica polytype in low-temperature metamorphosed sedimentary rocks. Schweizerische Mineralogische und Petrographische Mitteilungen, 77, 149-159.

Dalrymple, G. B., \& Lanphere, M. A. (1969). Potassium-argon dating: principles, techniques and applications to geochronology (p. 258). San Francisco: W.H. Freeman.

Decker, K., Feijth, J., Frieling, D., Frisch, W., Gruber, A., Kolenprat, B., et al. (2009). Blatt 148 Brenner 1:50,000. Vienna: Geologische Bundesanstalt.

Deer, W. A., Howie, R. A., \& Zussman, J. (1992). An introduction to rock-forming minerals (p. 696). Essex: Longman.

Derkowski, A., Szczerba, M., Środoń, J., \& Banaś, M. (2014). Radiogenic Ar retention in residual silica from acid-treated micas. Geochimica et Cosmochimica Acta, 128, 236-248.

Dodson, M. H. (1973). Closure temperature in cooling geochronological and petrological systems. Contributions to Mineralogy and Petrology, 40, 259-274.
Duvall, A. R., Clark, M. K., van der Pluijm, B. A., \& Li, C. (2011). Direct dating of Eocene reverse faulting in northeastern Tibet using Ar-dating of fault clays and low-temperature thermochronometry. Earth and Planetary Science Letters, 304, $520-526$

Engelder, J. T. (1974). Cataclasis and the generation of fault gouge. Geological Society of America Bulletin, 85, 1515-1522.

Feigenbaum, S., Edelstein, R., \& Shainberg, I. (1981). Release rate of potassium and structural cations from micas to ion exchangers in dilute solutions. Soil Science Society of America Journal, 45, $501-506$

Feigenbaum, S., \& Shainberg, I. (1975). Dissolution of illite-a possible mechanism of potassium release. Soil Science Society of America Journal, 39, 985-990.

Frank, W., Hoinkes, G., Purtscheller, F., \& Thöni, M. (1987). The Australpine unit west of the Hohe Tauern: the Ötztal-Stubai complex as an example for the Eoalpine metamorphic evolution. In H. W. Flügel, P. Faupl (Ed.), Geodynamics of the Eastern Alps (pp. 179-225). Vienna: Franz Deuticke.

Frisch, W. (1974). Die stratigraphisch-tektonische Gliederung der Schieferhülle und die Entwicklung des penninischen Raumes im westlichen Tauernfenster (Gebiet Brenner-Gerlospa $\beta$ ). Mitteilungen der Geologischen Gesellschaft in Wien, 66-67, 9-20.

Fügenschuh, B. (1995). Thermal and kinematic history of the Brenner Area (Eastern Alps, Tyrol). Ph.D. thesis, ETH-Zurich, p. 226.

Fügenschuh, B., Mancktelow, N. S., \& Seward, D. (2000). Cretaceous to Neogene cooling and exhumation history of the Oetztal-Stubai basement complex, eastern Alps: a structural and fission track study. Tectonics, 19, 905-918.

Fügenschuh, B., Seward, D., \& Mancktelow, N. (1997). Exhumation in a convergent orogen: the western Tauern window. Terra Nova, 9, 213-217.

Gébelin, A., Teyssier, C., Heizler, M. T., \& Mulch, A. (2015). Meteoric water circulation in a rolling-hinge detachment system (northern Snake Range core complex, Nevada). Geological Society of America Bulletin, 127, 149-161.

Glodny, J., Ring, U., \& Kuhn, A. (2008). Coeval high-pressure metamorphism, thrusting, strike-slip, and extensional shearing in the Tauern Window, Eastern Alps. Tectonics, 27, TC4004. doi:10.1029/2007tc002193.

Graf von Reichenbach, H., \& Rich, C. I. (1969). Potassium release from muscovite as influenced by particle size. Clays and Clay Minerals, 17, 23-29.

Grasemann, B., \& Mancktelow, N. S. (1993). Two-dimensional thermal modelling of normal faulting: the Simplon Fault Zone, Central Alps, Switzerland. Tectonophysics, 225, 155-165.

Haines, S. H., \& van der Pluijm, B. A. (2008). Clay quantification and Ar-Ar dating of synthetic and natural gouge: application to the Miocene Sierra Mazatan detachment fault, Sonora, Mexico. Journal of Structural Geology, 30, 525-538.

Haines, S. H., \& van der Pluijm, B. A. (2010). Dating the detachment fault system of the Ruby Mountains, Nevada: significance for the kinematics of low-angle normal faults. Tectonics, 29, TC4028. doi:10.1029/2009TC002552.

Hemley, J. J. (1959). Some mineralogical equilibria in the system $\mathrm{K}_{2} \mathrm{O}-$ $\mathrm{Al}_{2} \mathrm{O}_{3}-\mathrm{SiO}_{2}-\mathrm{H}_{2} \mathrm{O}$. American Journal of Science, 257, 241-270.

Hess, J. C., \& Lippolt, H. J. (1994). Compilation of K/Ar measurements on HD-B1 standard biotite; 1994 status report. In G. S. Odin (Ed.), Phanerozoic Time Scale (pp. 19-23). Paris: Bulletin de Liaison et d'information, IUGS Subcommission, Geochronology.

Hetzel, R., Zwingmann, H., Mulch, A., Gessner, K., Akal, C., Hampel, A., et al. (2013). Spatiotemporal evolution of brittle normal faulting and fluid infiltration in detachment fault systems: a case study from the Menderes Massif, western Turkey. Tectonics, 32, 364-376. 
Hnat, J. S., \& van der Pluijm, B. A. (2014). Fault gouge dating in the Southern Appalachians, USA. Geological Society of America Bulletin, 126, 639-651.

Hoernes, S., \& Friedrichsen, H. (1974). Oxygen isotope studies on metamorphic rocks of the western Hohe Tauern area (Austria). Schweizerische Mineralogische und Petrographische Mitteilungen, 54, 769-788.

Horninger, G., \& Weiss, E. H. (1980). Engineering geology in mountainous regions. Abhandlungen der Geologischen Bundesanstalt, 34, 257-286.

Hower, J., Hurley, P. M., Pinson, W. H., \& Fairbairn, H. W. (1963). The dependence of $\mathrm{K}-\mathrm{Ar}$ age on the mineralogy of various particle size ranges in a shale. Geochimica et Cosmochimica Acta, 27, 405-410.

Huang, W. L., Longo, J. M., \& Pevear, D. R. (1993). An experimentally derived kinetic model for smectite-to-illite conversion and its use as a geothermometer. Clays and Clay Minerals, 41, 162-177.

Hunziker, J. C., Frey, M., Clauer, N., Dallmeyer, R. D., Friedrichsen, H., Flehmig, W., et al. (1986). The evolution of illite to muscovite: mineralogical and isotopic data from the Glarus Alps, Switzerland. Contributions to Mineralogy and Petrology, 92, 157-180.

Inoue, A., Velde, B., Meunier, A., \& Touchard, G. (1988). Mechanism of illite formation during smectite-to-illite conversion in a hydrothermal system. American Mineralogist, 73, $1325-1334$.

Kisch, H. J. (1983). Mineralogy and petrology of burial diagenesis (burial metamorphism) and incipient metamorphism in clastic rocks. In G. Larsen, G. V. Chilingar (Eds.), Diagenesis in Sediments and Sedimentary Rocks, vol. 2. (pp. 289-493). Amsterdam: Elsevier.

Koller, F. (2003). 5th workshop of Alpine geological studies. Field trip guide E5. Low $\mathrm{T}$-high $\mathrm{P}$ metamorphism in the Tarntal Mountains (Lower Austroalpine Unit). Geologisch-Paläontologische Mitteilungen Innsbruck, 26, 47-59.

Kralik, M., Klima, K., \& Riedmüller, G. (1987). Dating fault gouges. Nature, 327, 315-317.

Liewig, N., Clauer, N., \& Sommer, F. (1987). Rb-Sr and K-Ar dating of clay diagenesis in Jurassic sandstone oil-reservoir, North-Sea. American Association of Petroleum Geologists (AAPG) Bulletin, $71,1467-1474$.

Linzer, H.-G., Decker, K., Peresson, H., Dell'Mour, R., \& Frisch, W. (2002). Balancing lateral orogenic float of the Eastern Alps. Tectonophysics, 354, 211-237.

Lyons, J. B., \& Snellenburg, J. (1971). Dating Faults. Geological Society of America Bulletin, 82, 1749-1752.

Madritsch, H., \& Millen, B. (2007). Hydrogeologic evidence for a continuous basal shear zone within a deep-seated gravitational slope deformation (Eastern Alps, Tyrol, Austria). Landslides, 4, 149-162.

Mancktelow, N. S. (1985). The Simplon line: a major displacement zone in the western Lepontine Alps. Eclogae Geologicae Helvetiae, 78, 73-96.

Mancktelow, N. S. (1992). Neogene lateral extension during convergence in the Central Alps: evidence from interrelated faulting and backfolding around the Simplonpass (Switzerland). Tectonophysics, 215, 295-317.

Maxwell, D. T., \& Hower, J. (1967). High-grade diagenesis and lowgrade metamorphism of illite in the Precambrian Belt series. American Mineralogist, 52, 843.

McDougall, I., \& Roksandic, Z. (1974). Total fusion ${ }^{40} \mathrm{Ar} /{ }^{39} \mathrm{Ar}$ ages using HIFAR reactor. Journal of the Geological Socety of Australia, 21, 81-89.

Merriman, R. J., \& Frey, M. (1999). Patterns of very low-grade metamorphism in metapelitic rocks. In M. Frey, D. Robinson
(Eds.), Low-Grade Metamorphism (pp. 61-107). Malden: Blackwell Science.

Merriman, R. J., \& Roberts, B. (1985). A survey of white mica crystallinity and polytypes in pelitic rocks of Snowdonia and llyn, North-Wales. Mineralogical Magazine, 49, 305-319.

Meyer, C., \& Hemley, J. (1957). Hydrothermal alteration in some granodiorites. Clays and Clay Minerals, 6, 89-100.

Moore, D. M., \& Reynolds, R. C., Jr (1997). X-ray diffraction and the identification and analysis of clay minerals (p. 378). Oxford: Oxford University Press.

Mulch, A., \& Cosca, M. A. (2004). Recrystallization or cooling ages: in situ UV-laser ${ }^{40} \mathrm{Ar} /{ }^{39} \mathrm{Ar}$ geochronology of muscovite in mylonitic rocks. Journal of the Geological Society, 161, 573-582.

Mulch, A., Cosca, M. A., Andresen, A., \& Fiebig, J. (2005). Time scales of deformation and exhumation in extensional detachment systems determined by high-spatial resolution in situ UV-laser ${ }^{40} \mathrm{Ar} /{ }^{39} \mathrm{Ar}$ dating. Earth and Planetary Science Letters, 233, 375-390.

Mulch, A., Cosca, M. A., \& Handy, M. R. (2002). In-situ UV-laser ${ }^{40} \mathrm{Ar} /{ }^{39} \mathrm{Ar}$ geochronology of a micaceous mylonite: an example of defect-enhanced argon loss. Contributions to Mineralogy and Petrology, 142, 738-752.

Mulch, A., Teyssier, C., Cosca, M. A., Vanderhaeghe, O., \& Vennemann, T. W. (2004). Reconstructing paleoelevation in eroded orogens. Geology, 32, 525-528.

Odin, D. S., et al. (1982). Interlaboratory standards for dating purposes. In D. S. Odin (Ed.), Numerical Dating in Stratigraphy. Part 1 (pp. 123-148). Chichester: Wiley.

Paschinger, H. (1953). Der Tonaufschluß bei der Stefansbrücke im unteren Silltal. Verhandlungen der Geologischen Bundesanstalt, 1953, 132-135.

Pevear, D. R. (1999). Illite and hydrocarbon exploration. Proceedings of the National Academy of Sciences, 96, 3440-3446.

Piber, A., \& Tropper, P. (2007). Muscovite-chlorite-quartz thermobarometry of the Permian metamorphic overprint of the central part of the western Innsbruck Quartzphyllite Complex (Tyrol, Austria). Mitteilungen der Österreichischen Mineralogischen Gesellschaft, 153, 291-300.

Piber, A., Tropper, P., \& Mirwald, P. W. (2008). The metamorphic evolution of the Patscherkofel Crystalline Complex (Tyrol, Eastern Alps, Austria). Austrian Journal of Earth Sciences, 101, 27-35.

Pleuger, J., Mancktelow, N., Zwingmann, H., \& Manser, M. (2012). $\mathrm{K}$-Ar dating of synkinematic clay gouges from Neoalpine faults of the Central, Western and Eastern Alps. Tectonophysics, 550, $1-16$.

Prey, S. (1989). Ein steilstehendes Störungssystem als Westbegrenzung des Tauernfensters. Jahrbuch der Geologischen Bundesanstalt Wien, 132, 745-749.

Purtscheller, F., Haas, R., Hoinkes, G., Mogessie, A., Tessadri, R., \& Veltman, C. (1987). Eoalpine metamorphism in the crystalline basement. In H. W. Fluegel, P. Faupl (Eds.), Geodynamics of the Eastern Alps (pp. 185-190). Vienna: Franz Deuticke.

Pytte, A. M., \& Reynolds, R. C. (1989). The thermal transformation of smectite to illite. In N. D. Naeser, T. H. McCulloch (Eds.), Thermal history of sedimentary basins: methods and case histories (pp. 133-140). New York: Springer.

Ratschbacher, L., Frisch, W., Linzer, H.-G., \& Merle, O. (1991). Lateral extrusion in the eastern Alps, Part 2: structural analysis. Tectonics, 10, 257-271.

Reiter, F., Lenhardt, W. A., \& Brandner, R. (2005). Indications for activity of the Brenner Normal Fault zone (Tyrol, Austria) from seismological and GPS data. Austrian Journal of Earth Sciences, 97, 16-23.

Reynolds, R. C, Jr. (1963). Potassium-rubidium ratios aud polymorphism in illites and microclines from the clay size fractions of 
proterozoic carbonate rocks. Geochimica et Cosmochimica Acta, 27, 1097-1112.

Rieder, M., Cavazzini, G., D’Yakonov, Y. S., Frank-Kamenetskii, V. A., Gottardi, G., Guggenheim, S., et al. (1999). Nomenclature of the micas. Mineralogical Magazine, 63, 267-279.

Rockenschaub, M., Kolenprat, B., \& Frank, W. (2003). Geochronologische Daten aus dem Brennergebiet: Steinacher Decke, Brennermesozoikum, Ötz-Stubai-Kristallin, Innsbrucker Quarzphyllitkomplex, Tarntaler Mesozoikum. Geologische Bundesanstalt-Arbeitstagung 2003: Blatt 148 Brenner, (pp. 117-124).

Rosenberg, P. E. (2002). The nature, formation, and stability of endmember illite: a hypothesis. American Mineralogist, 87, 103-107.

Rosenberg, C., \& Garcia, S. (2011). Estimating displacement along the Brenner Fault and orogen-parallel extension in the Eastern Alps. International Journal of Earth Sciences, 100, 1129-1145.

Rutter, E. H., Maddock, R. H., Hall, S. H., \& White, S. H. (1986). Comparative microstructures of natural and experimentally produced clay-bearing fault gouges. Pure and Applied Geophysics, 124, 3-30.

Schleicher, A., Warr, L., Kober, B., Laverret, E., \& Clauer, N. (2006). Episodic mineralization of hydrothermal illite in the Soultz-sousForêts granite (Upper Rhine Graben, France). Contributions to Mineralogy and Petrology, 152, 349-364.

Schmidegg, O. (1953). Die Silltalstörung und das Tonvorkommen bei der Stefansbrücke (südlich Innsbruck). Verhandlungen der Geologischen Bundesanstalt, 1953, 135-138.

Schmidegg, O. (1964). Die Ötztaler Schubmasse und ihre Umgebung. Verhandlungen der Geologischen Bundesanstalt, 1964, 27-47.

Scott, A. D., \& Reed, M. G. (1966). Expansion of potassium depeleted muscovite. Clays and Clay Minerals, 13, 247-261.

Scott, A. D., \& Smith, S. J. (1966). Susceptibility of interlayer potassium in micas to exchange with sodium. In S. W. Bailey (Ed.), Clays and Clay Minerals (pp. 69-81). Pergamon.

Selverstone, J. (1988). Evidence for east-west crustal extension in the Eastern Alps: implications for the unroofing history of the Tauern Window. Tectonics, 7, 87-105.

Sibson, R. H., White, S., \& Atkinson, B. K. (1979). Fault rock distribution and structure within the Alpine Fault Zone: a preliminary account. In R. I. Walcot, M. M. Cresswell (Eds.), The Origin of the Southern Alps, vol. 18 (pp. 55-66) Bulletin of the Royal Society of New Zealand.

Solum, J. G., Davatzes, N. C., \& Loaner, D. A. (2010). Fault-related clay authigenesis along the Moab Fault: implications for calculations of fault rock composition and mechanical and hydrologic fault zone properties. Journal of Structural Geology, 32, 1899-1911.

Solum, J. G., \& van der Pluijm, B. A. (2007). Reconstructing the Snake River-Hoback River Canyon section of the Wyoming thrust belt through direct dating of clay-rich fault rocks. In J. W. Sears, T. A. Harms, C. A. Evenchick (Eds.), Whence the Mountains? Inquiries into the Evolution of Orogenic Systems: A Volume in Honor of Raymond A. Price, vol. 433 (pp. 183-196). Geological Society of America Special Paper.

Solum, J. G., van der Pluijm, B. A., \& Peacor, D. R. (2005). Neocrystallization, fabrics and age of clay minerals from an exposure of the Moab Fault, Utah. Journal of Structural Geology, 27, 1563-1576.

Song, Y., Chung, D., Choi, S.-J., Kang, I.-M., Park, C., Itaya, T., \& Yi, K. (2014). K-Ar illite dating to constrain multiple events in shallow crustal rocks: implications for the Late Phanerozoic evolution of NE Asia. Journal of Asian Earth Sciences, 95, 313-322.

Song, S. K., \& Huang, P. M. (1988). Dynamics of potassium release from potassium-bearing minerals as influenced by oxalic and citric acids. Soil Science Society of America Journal, 52, 383-390.

Steiger, R. H., \& Jäger, E. (1977). Subcommission on geochronology: convention on the use of decay constants in geo- and cosmochronology. Earth and Planetary Science Letters, 36, 359-362.

Stipp, M., Stunitz, H., Heilbronner, R., \& Schmid, S. M. (2002). The eastern Tonale fault zone: a 'natural laboratory' for crystal plastic deformation of quartz over a temperature range from 250 to 700 degrees C. Journal of Structural Geology, 24, 1861-1884.

Surace, I. R., Clauer, N., Thélin, P., \& Pfeifer, H.-R. (2011). Structural analysis, clay mineralogy and $\mathrm{K}-\mathrm{Ar}$ dating of fault gouges from Centovalli Line (Central Alps) for reconstruction of their recent activity. Tectonophysics, 510, 80-93.

Teichmüller, M., \& Teichmüller, R. (1978). Coalification studies in the Alps. In H. Cloos, D. Roeder, K. Schmidt (Eds.), Alps, Appenines, Hellenides (pp. 49-55). Stuttgart: Schweizerbart.

Thoni, M. (1999). A review of geochronological data from the Eastern Alps. Schweizerische Mineralogische und Petrographische Mitteilungen, 79, 209-230.

Thöni, M. (1980). Distribution of pre-Alpine and Alpine metamorphism of the southern Ötztal Mass and the Scarl Unit, based on $\mathrm{K} / \mathrm{Ar}$ age determinations. Mitteilungen der österreichische Geologische Gesellschaft, 71(72), 139-165.

Thöni, M., \& Hoinkes, G. (1987). The southern Ötztal basement: geochronological and petrological consequences of Eoalpine metamorphic overprinting. In H. W. Fluegel, P. Faupl (Eds.), Geodynamics of the Eastern Alps (pp. 200-213). Vienna: Franz Deuticke.

Töchterle, A., Brandner, R., \& Reiter, F. (2011). Strain partitioning on major fault zones in the northwestern Tauern Window-insights from the investigations to the Brenner Base Tunnel. Austrian Journal of Earth Sciences, 104, 15-35.

Torgersen, E., \& Viola, G. (2014). Structural and temporal evolution of a reactivated brittle-ductile fault-Part I: fault architecture, strain localization mechanisms and deformation history. Earth and Planetary Science Letters, 407, 205-220.

Torgersen, E., Viola, G., Zwingmann, H., \& Harris, C. (2014a). Structural and temporal evolution of a reactivated brittle-ductile fault-Part II: timing of fault initiation and reactivation by K-Ar dating of synkinematic illite/muscovite. Earth and Planetary Science Letters, 407, 221-233.

Torgersen, E., Viola, G., Zwingmann, H., \& Henderson, I. H. C. (2014b). Inclined K-Ar illite age spectra in brittle fault gouges: effects of fault reactivation and wall-rock contamination. Terra Nova, doi:10.1111/ter.12136.

Van der Pluijm, B. A., Hall, C. M., Vrolijk, P. J., Pevear, D. R., \& Covey, M. C. (2001). The dating of shallow faults in the Earth's crust. Nature, 412, 172-175.

van der Pluijm, B. A., Vrolijk, P. J., Pevear, D. R., Hall, C. M., \& Solum, J. (2006). Fault dating in the Canadian Rocky Mountains evidence for late Cretaceous and early Eocene orogenic pulses. Geology, 34, 837-840.

Van Diggelen, E. W. E., De Bresser, J. H. P., Peach, C. J., \& Spiers, C. J. (2010). High shear strain behaviour of synthetic muscovite fault gouges under hydrothermal conditions. Journal of Structural Geology, 32, 1685-1700.

Velde, B. (1965). Experimental determination of muscovite polymorph stabilities. American Mineralogist, 50, 436-449.

Villa, I. M. (1998). Isotopic closure. Terra Nova, 10, 42-47.

Viola, G., Zwingmann, H., Mattila, J., \& Käpyaho, A. (2013). K-Ar illite age constraints on the Proterozoic formation and reactivation history of a brittle fault in Fennoscandia. Terra Nova, 25, 236-244.

von Klebelsberg, R. (1935). Geologie von Tirol (p. 872). Berlin: Borntraeger. 
Vrolijk, P., \& van der Pluijm, B. A. (1999). Clay gouge. Journal of Structural Geology, 21, 1039-1048.

Wemmer, K., \& Ahrendt, H. (1997). Comparative K-Ar and Rb-Sr age determinations of retrograde processes on rocks from the KTB deep drilling project. Geologische Rundschau, 86(Suppl 1), S272-S285.

White, J. C., \& White, S. H. (1983). Semi-brittle deformation within the Alpine Fault Zone, New Zealand. Journal of Structural Geology, 5, 579-589.

Wilson, J. (2013). Rock-forming minerals: sheet silicates: clay minerals, vol. 3C (p. 724). London: The Geological Society.

Yamasaki, S., Zwingmann, H., Yamada, K., Tagami, T., \& Umeda, K. (2013). Constraining the timing of brittle deformation and faulting in the Toki granite, central Japan. Chemical Geology, $351,168-174$.

Yates, D. M., \& Rosenberg, P. E. (1997). Formation and stability of endmember illite: II. Solid equilibration experiments at 100 to $250^{\circ} \mathrm{C}$ and $\mathrm{Pv}$, soln. Geochimica et Cosmochimica Acta, 61, $3135-3144$.

Yates, D. M., \& Rosenberg, P. E. (1998). Characterization of neoformed illite from hydrothermal experiments at $250{ }^{\circ} \mathrm{C}$ and $P_{\mathrm{v}, \text { soln: }}$ an HRTEM/ATEM study. American Mineralogist, 83, 1199-1208.

Ylagan, R. F., Altaner, S. P., \& Pozzuoli, A. (2000). Reaction mechanisms of smectite illitization associated with hydrothermal alteration from Ponza Island, Italy. Clays and Clay Minerals, 48, 610-631.

Ylagan, R. F., Kim, C. S., Pevear, D. R., \& Vrolijk, P. J. (2002). Illite polytype quantification for accurate $\mathrm{K}-\mathrm{Ar}$ age determination. American Mineralogist, 87, 1536-1545.

Yoder, H. S, Jr. (1957). Experimental studies on micas: a synthesis. Clays and Clay Minerals, 6, 42-60.

Yoder, H. S, Jr, \& Eugster, H. P. (1955). Synthetic and natural muscovites. Geochimica et Cosmochimica Acta, 8, 225-280.

Zwingmann, H., Han, R., \& Ree, J. H. (2011). Cretaceous reactivation of the Deokpori Thrust, Taebaeksan Basin, South Korea, constrained by K-Ar dating of clayey fault gouge. Tectonics, 30, TC5015. doi:10.1029/2010tc002829.

Zwingmann, H., \& Mancktelow, N. (2004). Timing of Alpine fault gouges. Earth and Planetary Science Letters, 223, 415-425.

Zwingmann, H., Mancktelow, N., Antognini, M., \& Lucchini, R. (2010a). Dating of shallow faults: new constraints from the AlpTransit tunnel site (Switzerland). Geology, 38, 487-490.

Zwingmann, H., Offler, R., Wilson, T., \& Cox, S. F. (2004). K-Ar dating of fault gouge in the northern Sydney Basin, NSW, Australia-implications for the breakup of Gondwana. Journal of Structural Geology, 26, 2285-2295.

Zwingmann, H., Yamada, K., \& Tagami, T. (2010b). Timing of brittle deformation within the Nojima fault zone, Japan. Chemical Geology, 275, 176-185. 